\title{
Planejamento urbano sustentável: um estudo para implantação de infraestrutura verde no Bairro Bancários, João Pessoa-PB, Brasil
}

Sustainable urban planning: a study for the implementation of green infrastructure in Bancários, João Pessoa-PB, Brazil

Vivianne Lisbethe Bezerra Maropo[a] $@$, Emilia Evangelista Morais[a], André Cavalcanti Nunes[a], José Augusto Ribeiro da Silveira[a]

[a] Universidade Federal da Paraíba (UFPB), João Pessoa, PB, Brasil

Como citar: Maropo, V. L. B., Morais, E. E., Nunes, A. C., \& Silveira, J. A. R. (2019). Planejamento urbano sustentável: um estudo para implantação de infraestrutura verde no Bairro Bancários, João Pessoa-PB, Brasil. urbe. Revista Brasileira de Gestão Urbana, 11, e20180005. https://doi.org/10.1590/2175-3369.011.002.A009

\section{Resumo}

O modelo atual de planejamento urbano no Brasil oferta maiores possibilidades aos veículos motorizados, buscando assim soluções que beneficiem esse segmento, gerando impactos negativos à cidade. A implantação de infraestrutura verde no Bairro Bancários em João Pessoa-PB busca, através de medidas urbanísticas mais sustentáveis, aproximar a natureza ao espaço urbano, utilizando desses conceitos na diminuição dos impactos gerados no uso da infraestrutura cinza. Para sua aplicação, fez-se uma revisão bibliográfica sobre a infraestrutura verde e, em seguida, o diagnóstico e retrato dinâmico do bairro, para assim propor cenários alternativos que priorizam os conflitos e potencialidades observadas. Desse modo, a ênfase dos cenários seguiu os conceitos da Mobilidade Urbana, Sustentabilidade e Uso, Ocupação e Desenvolvimento Urbano, criados a partir das características dos bons espaços públicos ditas por autores conceituados. Por fim, é proposta uma série de projetos que, alinhados com o conceito de infraestrutura verde, possibilitam um melhor aproveitamento do espaço público, propondo projetos urbanos mais sustentáveis e atentos às novas necessidades das cidades contemporâneas.

Palavras-chave: Sustentabilidade. Planejamento urbano. Infraestrutura verde.

\section{Abstract}

The current model of urban planning in Brazil offers greater possibilities to motor vehicles, thus seeking solutions that benefit this segment, generating negative impacts to the city. The implantation of green infrastructure in the Bancários district in João Pessoa-PB seeks through more sustainable urban measures, bringing nature closer to urban space, using these concepts to reduce the impacts generated by the use of gray infrastructure. For its application, a bibliographic review was done on the green infrastructure, and then the diagnosis and dynamic portrayal of the neighborhood, in order to propose alternative scenarios that prioritize the conflicts and potentialities observed. Thus emphasis of the scenarios followed the concepts of Urban Mobility, Sustainability, and Urban Use, Occupation and Development, created from the characteristics of good public spaces spoken by renowned authors. Finally, a series of projects are proposed

VLBM é graduada em Arquitetura e Urbanismo, e-mail: viviannemaropo@gmail.com

EEM é graduada em Arquitetura e Urbanismo, e-mail: emiliaemorais@gmail.com

ACN é graduado em Arquitetura e Urbanismo, e-mail: andrecn92@gmail.com

JARS é doutor em Desenvolvimento Urbano, e-mail: ct.laurbe@gmail.com 
that, in line with the concept of green infrastructure, allows a better use of the public space, proposing more sustainable urban projects and attentive to the new needs of contemporary cities.

Keywords: Sustainability. Urban planning. Green infrastructure.

\section{Introdução}

Nas últimas décadas, muito se tem atuado na conscientização mundial frente a situações de eventos climáticos extremos que podem ser enfrentados pelas populações urbanas, sendo estas últimas as maiores causadoras desses problemas, que se mostram como resultado de um "efeito dominó" constituído por um considerável número de problemas urbanos, em ciclo vicioso acelerado. Seguindo o pensamento de Rogers (2001, p. 4), que acredita que "o simples fato de morar em uma cidade não deveria conduzir à autodestruição da civilização" e que "as cidades futuras podem ser o trampolim para restaurar a harmonia da humanidade com seu meio ambiente", surge a inquietação para os problemas vividos hoje nas cidades brasileiras. Logo, é necessário um novo modo de "pensar a cidade", constituindo o nosso dever e direito de procurar novas soluções de planejamento urbano sustentáveis que sejam resilientes aos impactos das cidades.

As cidades latino-americanas têm seu crescimento urbano baseado no modelo americano (Urban Sprawl) que se caracteriza pelo crescimento desordenado das cidades, possibilitado pelo fordismo, pela tendência da migração rural-urbana e pela especulação imobiliária.

À medida que os deslocamentos rodoviários passam a estruturar cada vez mais o crescimento metropolitano latino-americano, principalmente pelo uso do automóvel, as aglomerações urbanas fortalecem o adensamento das principais vias de transportes, consolidando uma tendência já presente no período anterior. Isso intensificou a formação de corredores e anéis viários, conformando o espaço de fluxos, conceito descrito por Castells (2012 apud Bentes, 2014, p. 194).

0 aspecto da automobilização da sociedade contribui para dispersão urbana que atua de forma direta e negativa na sustentabilidade das cidades. A dependência do automóvel em estruturas urbanas que distanciam áreas de trabalho e moradia tende a ter o modelo de crescimento pautado no espraiamento urbano, criando uma necessidade de maiores vias que conectem essas áreas mais afastadas aos centros urbanos. 0 acréscimo dessas vias contribui para o aumento de automóveis circulando nas ruas, ampliando em rápida escala o congestionamento do trânsito. Com isso, as cidades passam a ser mais poluídas, com altos níveis de ruídos e solos menos permeáveis, tornando-as menos eficientes, sustentáveis e inteligentes.

0 termo "Infraestrutura Verde" vem ganhando espaço nas novas discussões de planejamento das cidades. Benedict \& McMahon (2006, p. 1) irão defini-la como

[...] uma rede de conexões de áreas naturais e outros espaços abertos que possibilitam a conservação dos valores e funções do ecossistema natural, garantindo a saúde ambiental, social e econômica dos espaços [...] e incentivando o planejamento do uso do solo e práticas que sejam eficientes para a natureza e para as pessoas.

As formas de ocupação, planejamento e de "pensar a cidade", na urbe de João Pessoa, Paraíba, não difere do pensamento de "cidades para carros" que acontece na maioria das cidades brasileiras. Ao longo dos tempos, o congestionamento de carros, as novas aberturas de vias, a ocupação das áreas de preservação ambiental e o espraiamento urbano vêm aproximando a dinâmica da cidade de um verdadeiro caos. Um dos bairros da capital paraibana mais críticos, alvo dessa problemática, é o Bairro Bancários, que foi "estrangulado" pela expansão dos bairros vizinhos e hoje sofre as consequências de um trânsito problemático, acessibilidade deficiente, escassos espaços de lazer públicos e péssimo sistema de arborização.

Dessa forma, este artigo visa discutir as possibilidades e as vantagens de se desenvolver uma infraestrutura verde em áreas urbanas onde já se tem uma ocupação e infraestrutura cinza consolidada, 
tendo como objeto de estudo o Bairro Bancários na cidade de João Pessoa, Paraíba. 0 artigo se inicia com a conceituação e análise das aplicações da infraestrutura verde em cidades, discutindo os benefícios que ela pode trazer para o meio urbano. Em seguida, mostra-se a contextualização e o diagnóstico através do retrato dinâmico do bairro. Na sequência, introduz-se uma proposta de aplicação da infraestrutura verde no objeto em questão. Conclui-se com reflexões sobre a capacidade de adaptação dos espaços à implantação de políticas e projetos urbanos mais sustentáveis para as cidades contemporâneas.

\section{A infraestrutura verde}

O conceito infraestrutura verde vem sendo abordado em conferências em todo o mundo. Segundo Herzog \& Rosa (2010, p. 94), "o planejamento de uma infraestrutura verde propicia a integração da natureza na cidade, de modo que venha ser mais sustentável". A sua implantação traz alguns benefícios, como a diminuição de enchentes, a conservação de áreas naturais, melhoria na qualidade do ar, a proteção e recuperação da fauna e flora, entre outras.

A infraestrutura verde consiste em intervenções de baixo impacto na paisagem e alto desempenho, com espaços multifuncionais e flexíveis, que possam exercer diferentes funções ao longo do tempo - adaptável às necessidades futuras. Pode ser implantada em experiências locais que sejam safe-to-fail (seguras-para-falhar), sendo monitoradas para possíveis correções ao longo do tempo (Ahern, 2009 apud Herzog e Rosa, 2010, p. 98).

Algumas cidades estão utilizando o sistema de infraestrutura verde para adequar áreas urbanas já consolidadas, que apresentam em sua maioria a infraestrutura cinza, como diz Firehock:

O conceito de infraestrutura verde foi utilizado pela primeira vez em 1994, em um documento elaborado pela Florida Greenways Comission que apontava a importância dos sistemas naturais no contexto urbano, sendo até mais importantes que a infraestrutura convencional, chamada de cinza (Firehock, 2010 apud Hannes, 2015, p. 57).

A infraestrutura cinza engloba toda a infraestrutura convencional constituída por ruas, sistema de rede de esgoto e de água canalizados. A infraestrutura verde nasce com o conceito oposto, utilizando métodos naturais e tecnologias sustentáveis para auxiliar na recuperação de áreas degradadas pela urbanização desenfreada, pela grande perda de massa vegetativa das cidades e pela falta de métodos sustentáveis no planejamento urbano. A inserção dessas tecnologias verdes pode ainda representar processos mais econômicos quando comparadas com a cinza.

Como cita Cormier \& Pellegrino (2008), a infraestrutura verde é um modo de usufruir e retribuir os serviços que a natureza pode realizar no ambiente urbano. Os elementos que compõem essa rede de infraestrutura podem ser adaptados em quase todas as paisagens urbanas, tendo um impacto significativo no incremento da qualidade ambiental de áreas já urbanizadas. Os processos naturais podem ofertar para as cidades: o abastecimento de água, o tratamento das águas pluviais, a melhoria do microclima, o sequestro de carbono, etc. Mesmo tendo um impacto significativo em áreas já urbanizadas, a infraestrutura verde idealmente

deve ser planejada antes da ocupação, assim áreas frágeis e de grande valor ambiental podem ser conservadas, como: áreas alagadas, corredores ripários, encostas instáveis com risco de deslizamento e fragmentos de ecossistemas nativos (Herzog \& Rosa, 2010).

Para adequar as cidades à rede de infraestrutura verde, alguns elementos podem ser implementados (Figura 1), como os canteiros pluviais, que são pequenos jardins de chuva que recebem as águas de áreas impermeáveis, auxiliando na diminuição de carbono e moderando as ilhas de calor; as hortas urbanas, que, além de recuperar a relação direta da população com os alimentos, servem como áreas de infiltração e purificação; e as ruas verdes que priorizam os pedestres e ciclistas, que são ruas mais arborizadas que 
evitam o fluxo de veículos pesados, trazendo soluções de traffic calming, parques, corredores verdes e espaços naturais preservados.
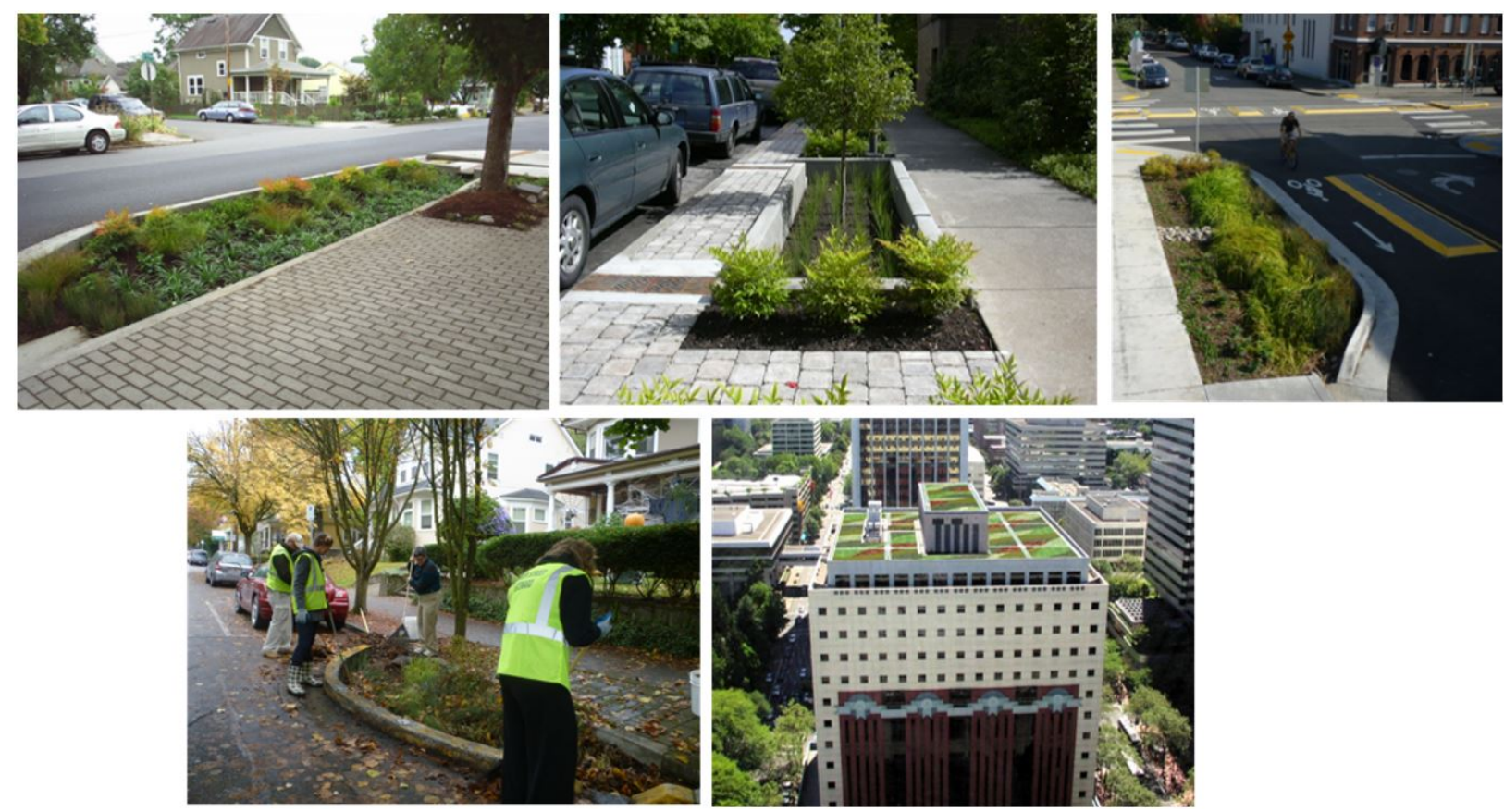

Figura 1 - Tipologias de infraestrutura verde na cidade de Portland, Oregon. Fonte: ABCP (2017).

\section{Diagnóstico e retrato dinâmico do Bairro Bancários}

O estudo de caso do artigo está inserido na cidade de João Pessoa - PB, no Brasil. Dentro da cidade, optou-se por abordar o Bairro Bancários, localizado no Setor Sudeste da cidade de João Pessoa, Paraíba (Figuras 2 e 3).

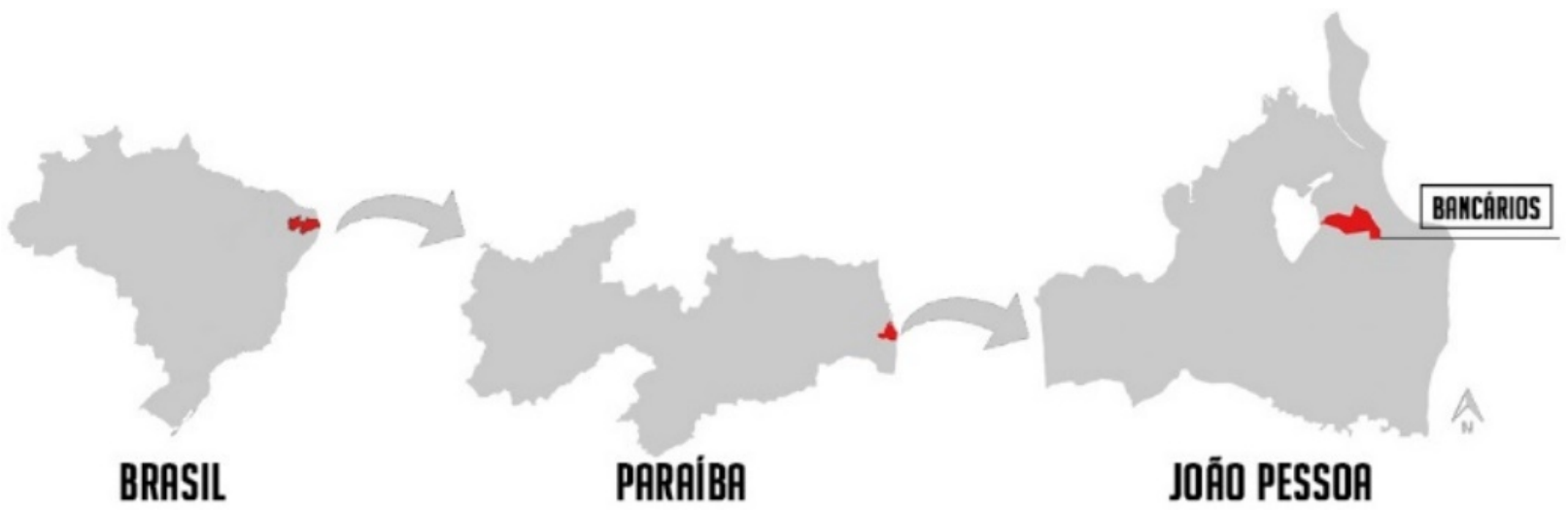

Figura 2 - Delimitação do objeto de estudo, o Bairro Bancários, na cidade de João Pessoa, Paraíba. Fonte: Autores, a partir da base de dados do LAURBE.

Segundo Negrão \& Silveira (2016), o processo de urbanização acelerado de João Pessoa iniciado no começo do século XX promoveu a implantação do Parque Sólon de Lucena no bairro do centro, onde a cidade esteve em formação por aproximadamente 300 anos, expandindo logo mais para o Bairro da Torre, que teve origem em finais da década de 1930. 


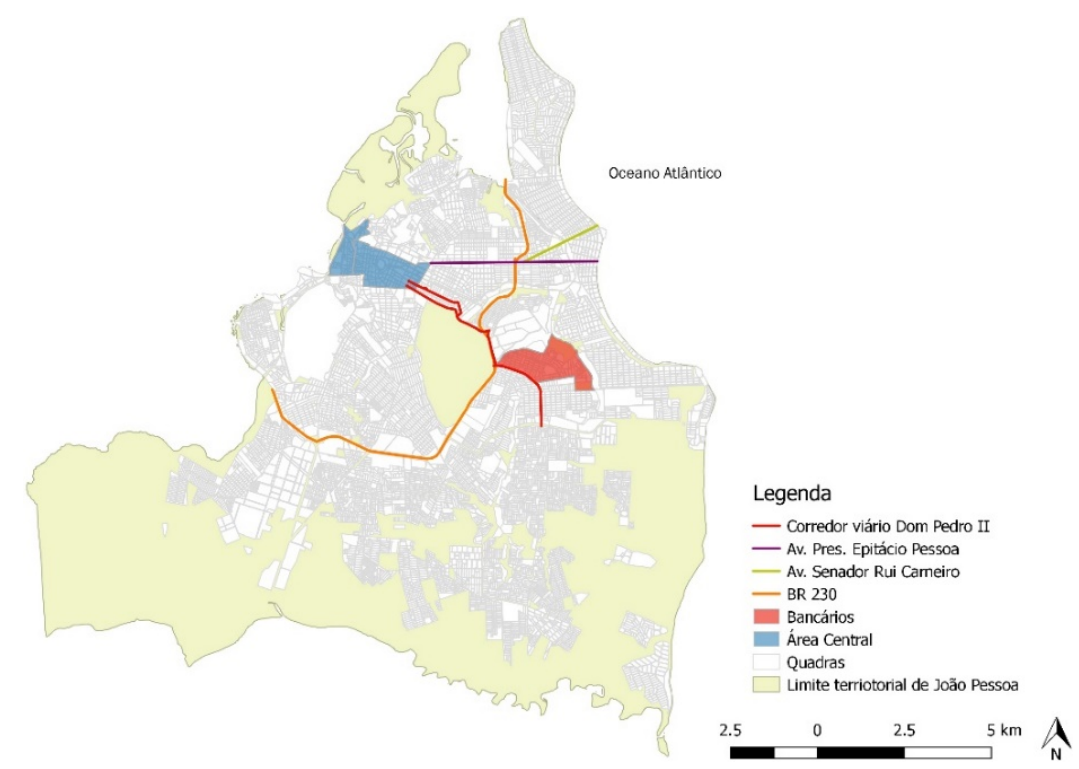

Figura 3 - Mapa de localização do Bairro Bancários em relação ao centro e às principais avenidas da cidade de João Pessoa, Paraíba. Fonte: Autores, a partir da base de dados do LAURBE.

Apesar da importância do Bairro da Torre no processo de expansão urbana de João Pessoa em direção a sudeste, verificou-se que o início do processo de ocupação e apropriação do setor sudeste, ocorreu, efetivamente, no início da década de 1960, com o avanço territorial sobre o Vale do Rio Jaguaribe, através da ampliação do sistema rodoviário, com a implantação de um anel rodoviário, composto pelas BR 101 e BR 230. [...] Junto à execução do anel rodoviário, outro acontecimento ganhou importância, a inserção do Campus Universitário em suas proximidades, que se caracterizou como um marco institucional na expansão urbana da cidade, uma vez que, induziu através da transferência das atividades universitárias que ocorriam no Bairro do Centro, o crescimento nessa direção (Negrão \& Silveira, 2016, p. 322).

Scocuglia (1999) destaca que em fins da década de 1960 notou-se a falta de aquisição de moradias pela população de baixa renda, o que aumentou o interesse do Estado pelas terras do Setor Sudeste (Figura 4), que pertenciam ao Governo do Estado - o que facilitaria na ocupação - e também por se tratar, na época, de uma área periférica. Foi assim que nasceram os conjuntos habitacionais do Castelo Branco (1968-1974), posteriormente os conjuntos habitacionais dos Bancários, Anatólia e Mangabeira (Figura 5), na década de 1980.

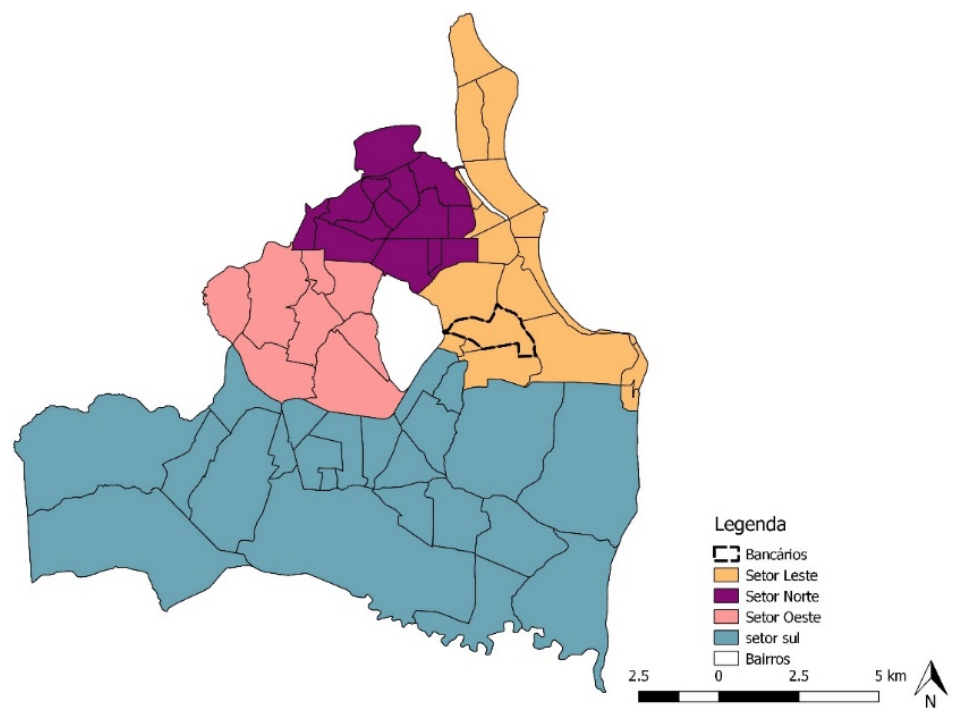

Figura 4 - Mapa de localização dos setores de João Pessoa. Fonte: Autores a partir da base de dados do LAURBE. 


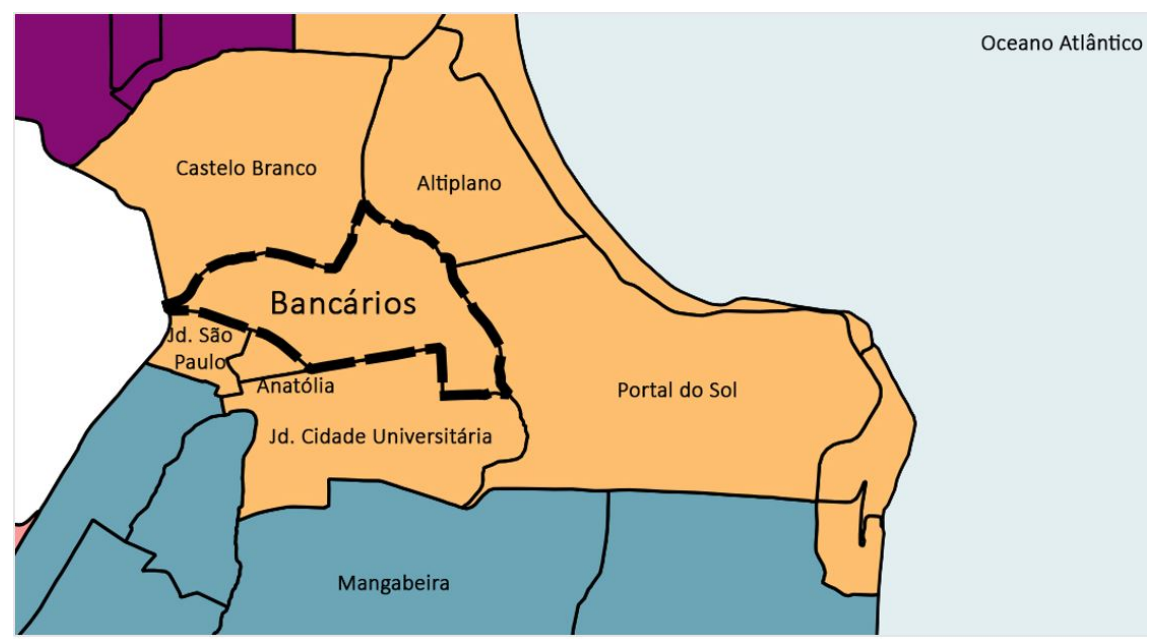

Figura 5 - Bairros vizinhos ao Bancários. Fonte: Autores, a partir da base de dados do LAURBE.

Essa ocupação se deu a partir da construção dos conjuntos habitacionais populares pelo BNH, em parceria com órgãos-gestores, como o Instituto de Orientação às Cooperativas Habitacionais INOCOOP - e a Companhia Estadual de Habitação Popular - CEHAP. Sendo os conjuntos Bancários e Anatólia, voltados para uma população de melhor renda e inseridos em espaços mais bem localizados - próximos da área central (Negrão \& Silveira, 2016, p. 328).

A fundação do Bairro Bancários aconteceu em 26 de abril de 1978. Inicialmente, o bairro foi ocupado por servidores da Caixa Econômica Federal, característica essa que implicou no nome do bairro e de algumas ruas, como a Avenida Sérgio Guerra, principal via dos Bancários. Com a implementação da Universidade Federal da Paraíba (UFPB), no Bairro Castelo Branco nos anos 1960, como dito acima, foi possível notar que a Instituição impulsionou o desenvolvimento em sua área circundante nas décadas seguintes, como se pode observar no mapa adiante (Figura 6).

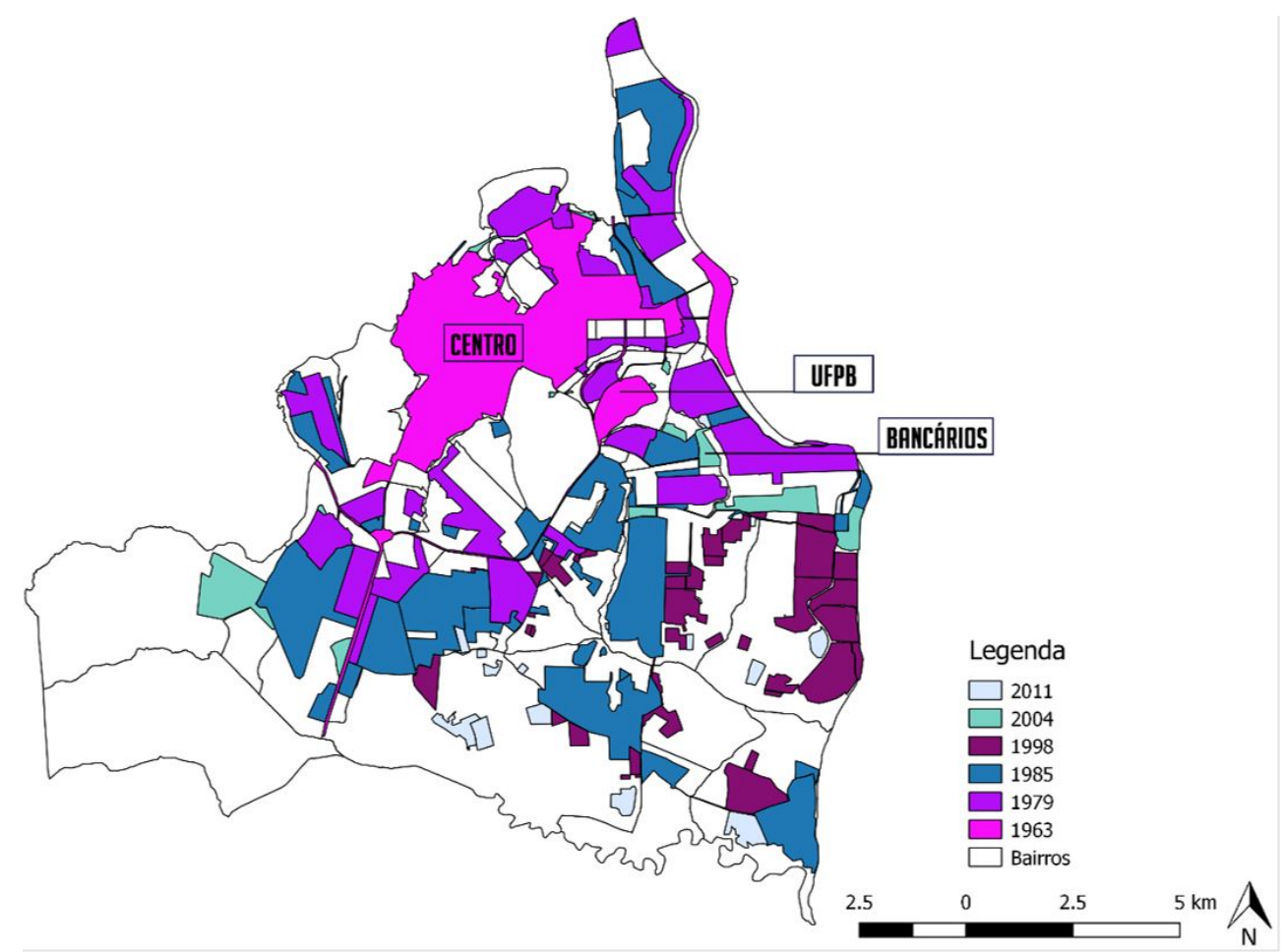

Figura 6 - Mapa de expansão da cidade de João Pessoa entre os anos de 1960 e 201 1. Fonte: Autores, a partir da base de dados do LAURBE. 
A UFPB tem influência na dinâmica do Bairro Bancários desde sua implantação, que está atrelada à fundação desta Universidade, até nos dias atuais, recebendo diversos universitários. Com sua consolidação e sendo área definida como Zona de Grandes Expansões (Figura 7), a Universidade Federal da Paraíba projeta-se como sendo uma área que tende a atrair ainda mais usuários, tendo rebatimento direto ao Bairro estudado.

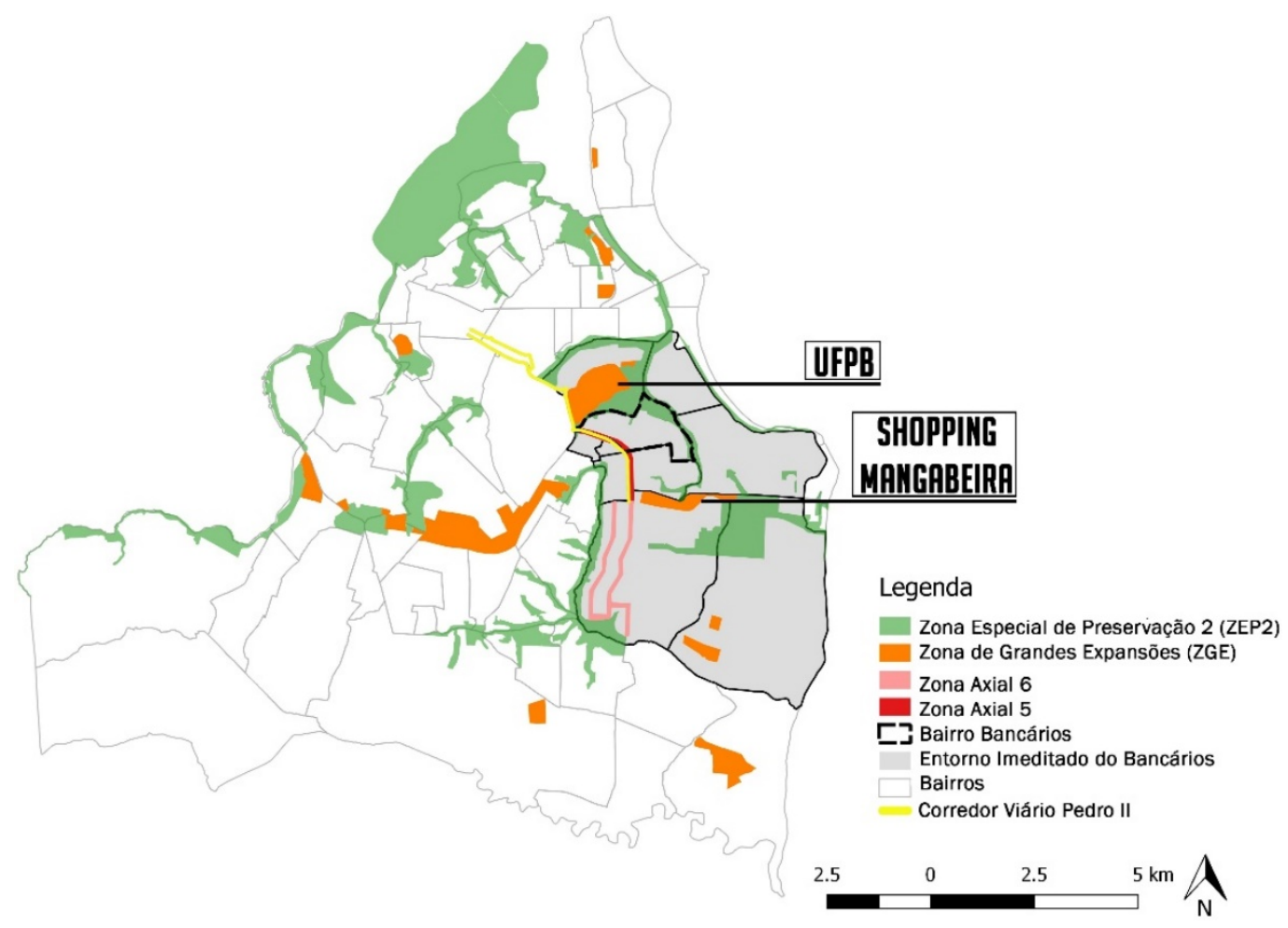

Figura 7 - Macrozoneamento do entorno imediato de maior influência para o Bairro Bancários. Fonte: Autores, a partir da base de dados do LAURBE.

O "Relatório de evolução dos bairros dos municípios de João Pessoa”, elaborado pela PMJP (2011), destacou a potencialidade da UFPB em atrair a população para o seu entorno. A prática de ocupação identificada no setor sudeste, faz com que esse território, atualmente, represente $10 \%$ da área total do município de João Pessoa, concentrando aproximadamente $20 \%$ da população e dos domicílios da cidade, em que, cerca de 10\% localizam-se em Mangabeira. (Negrão et al., 2016, p. 7)

Outra área de expansão, em Mangabeira, no entorno do recém-construído Mangabeira Shopping (Figura 7), mostra-se hoje como um local de instalação de grandes equipamentos, e por esse crescimento em curso e pungente, nos próximos anos acredita-se que essa área será de grande movimentação, tendo impacto direto nos Bancários, bairro que intermeia a conexão do centro e de outras importantes partes da cidade a essa região, visto que aí se encontra o eixo do corredor de transportes estrutural da cidade, ou seja, o corredor D. Pedro II.

A principal rua dos Bancários (Figura 8), Rua Empresário Rodrigues Alves (trecho do corredor D. Pedro II), que corta todo o bairro e é a principal via de acesso ao local, já mostra uma convergência ao congestionamento no tráfego de veículos, com tendência a se intensificar nos próximos anos, caso nenhuma ação seja tomada (Figura 9). Em contrapartida, o bairro conta com as "Três Ruas", apresentando um caráter de via local, quando poderia ter maior influência na mobilidade do bairro, tanto pela localização central no bairro como também pela grande largura, que permitiria receber maior tráfego de todos os tipos de modais. 


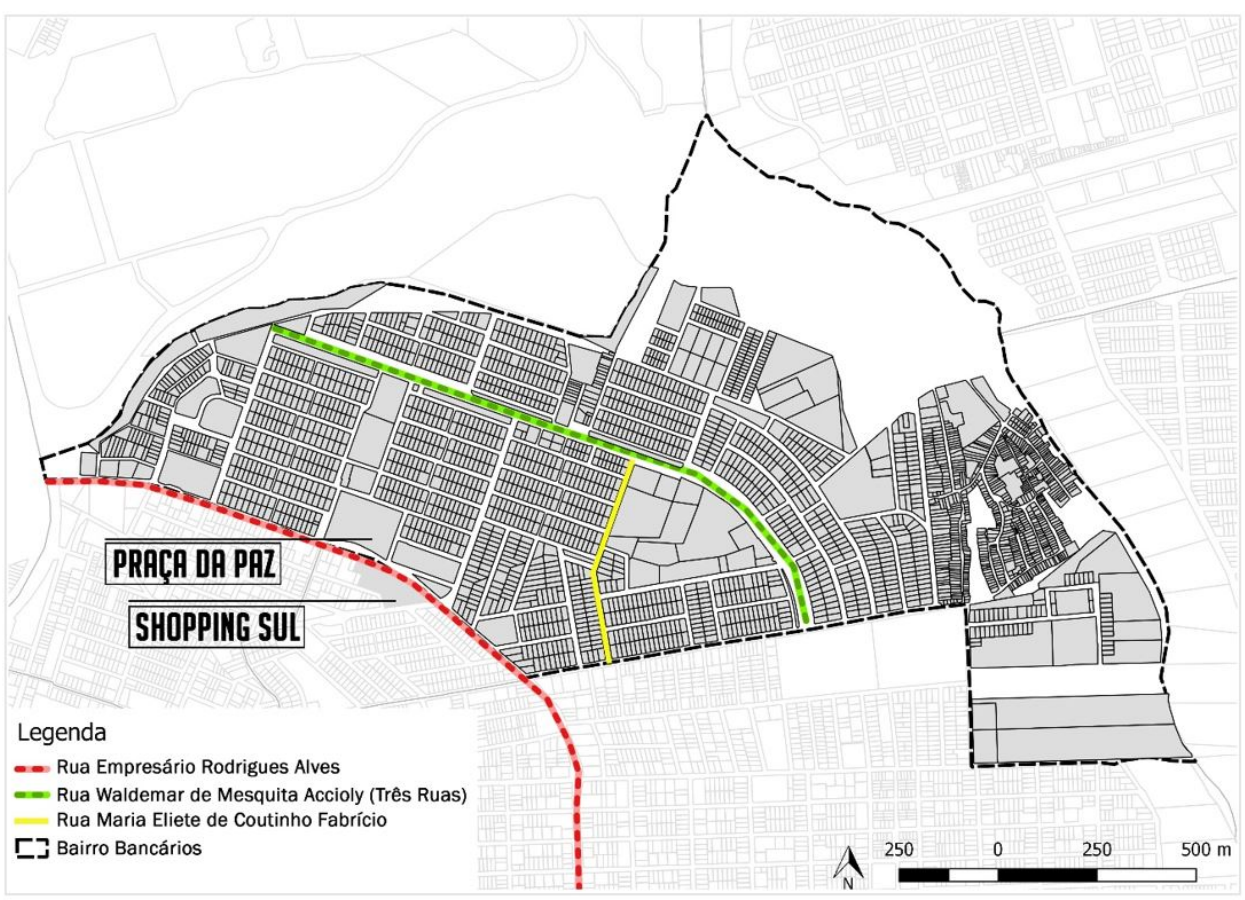

Figura 8 - Localização da principal avenida do Bancários e as "Três Ruas". Fonte: Autores, a partir da base de dados do LAURBE.

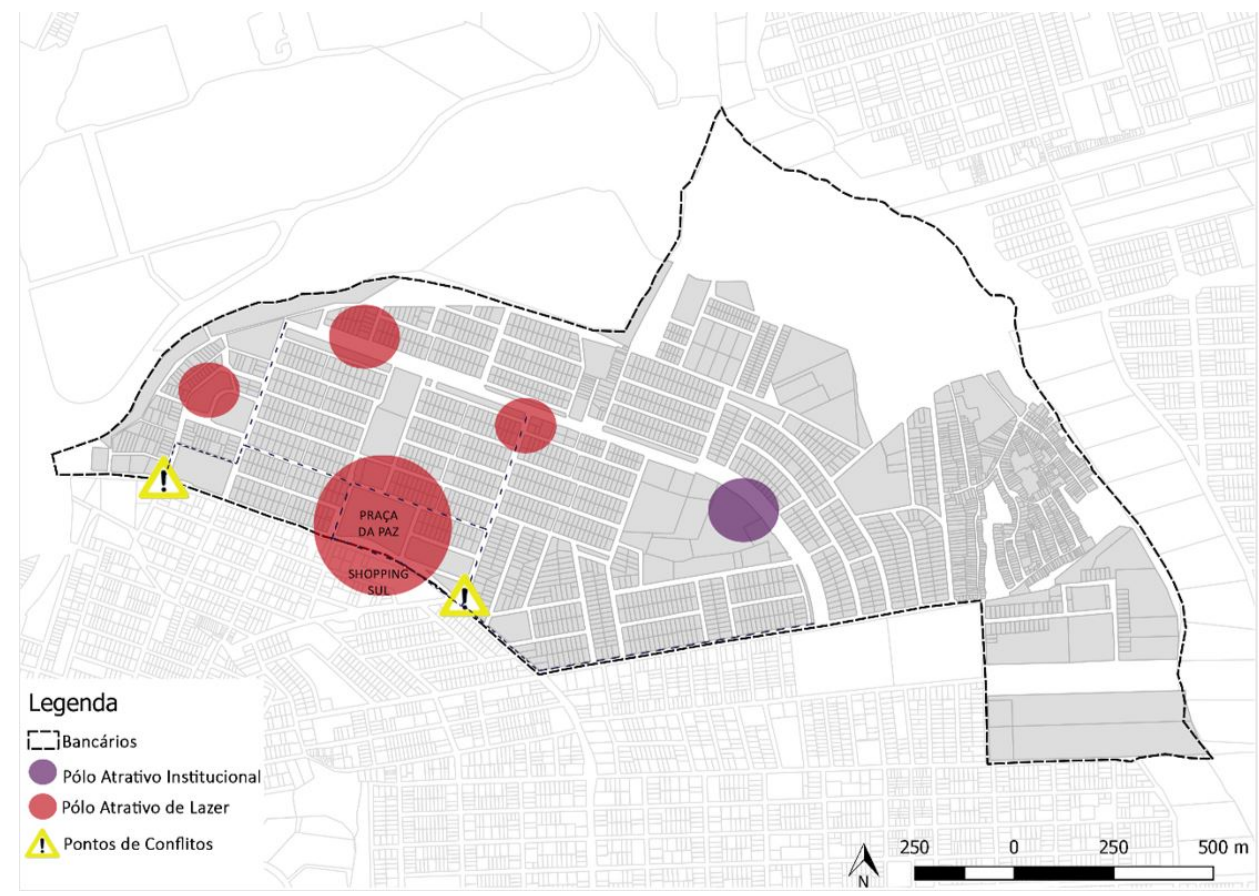

Figura 9 - Mapa de polos atrativos e pontos de conflitos do Bancários.Fonte: Autores, a partir da base de dados do LAURBE.

Na área central do bairro (Figura 8) - imediações da Praça da Paz e do Shopping Sul -, em decorrência da instalação desses equipamentos, tornou a presença de comércio e serviços bastante forte, aferindo um caráter de centralidade ao bairro, sendo a área de maior fluxo e concentração de pessoas. Com o excesso de crescimento dessa tipologia, é provável que novos locais de comércio sigam para outras regiões que hoje possuem um caráter mais residencial, como no caso da Rua Maria Eliete de Coutinho Fabrício (Figura 9), perpendicular às "Três Ruas", que com a formalização de uma praça em suas imediações, atraiu equipamentos que geraram maior movimentação, como bares, restaurantes e pequenos comércios. A Rua Waldemar de Mesquita Accioly (conhecida como "Três Ruas") também se mostra uma 
área atrativa a comércios e serviços, tanto por sua importância para o bairro, quanto por abrigar diversos equipamentos importantes.

Apesar do crescimento constante de comércios e serviços, o bairro ainda apresenta um caráter predominantemente residencial (Figura 10). 0 adensamento populacional nos Bancários é baixo, e as construções nos últimos anos apresentam uma tendência de edificações de até três pavimentos, o que poderia ser um fator positivo pela relação do pedestre com o morador, se a parte térrea dos edifícios tivesse o tratamento ideal às vivências da cidade, como fachadas mais permeáveis e ativas ao nível dos olhos no âmbito de usos mistos do solo, já que se trata de uma região de boa infraestrutura e de equipamentos, oferecendo potencial para ser mais adensada.

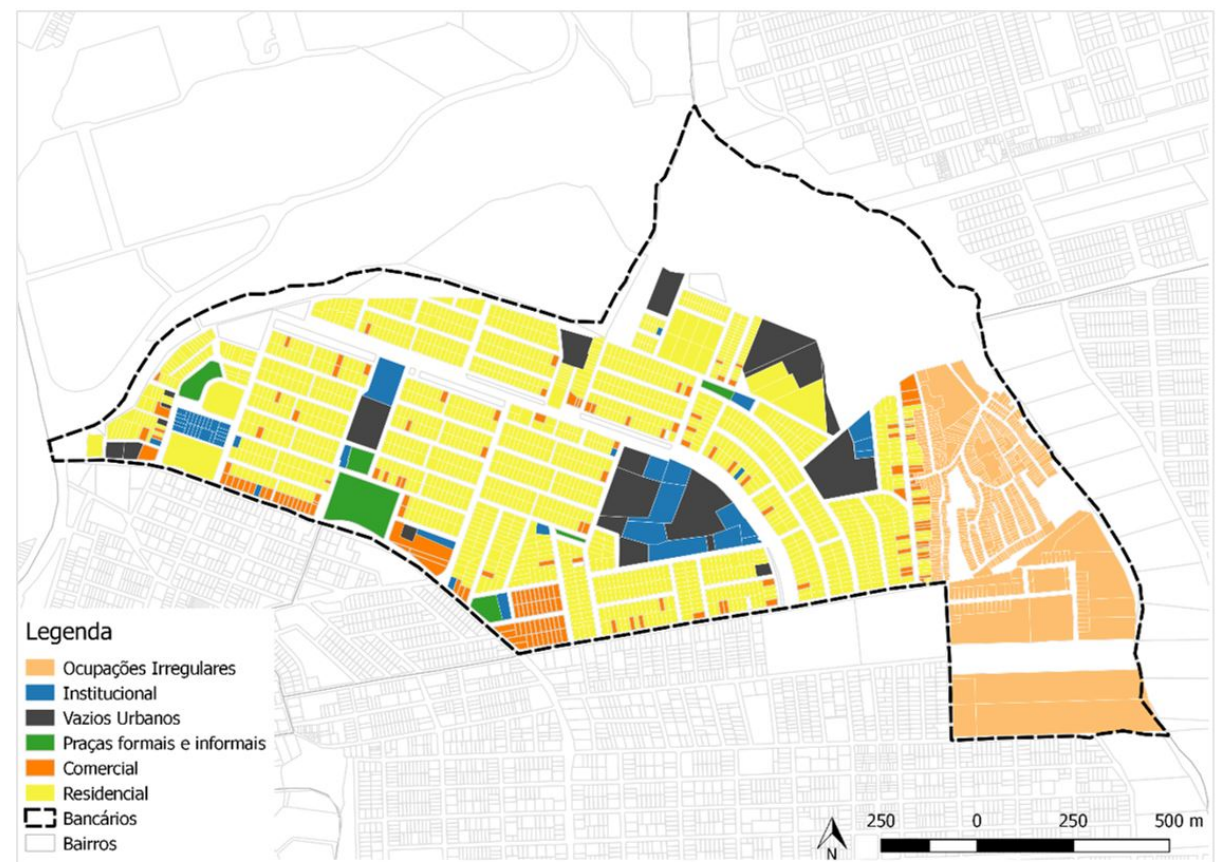

Figura 10 - Mapa de Uso e Ocupação do Bairro Bancários. Fonte: Autores, a partir da base de dados do LAURBE.

Moradores urbanos experienciam as suas cidades no que chamamos de a 'esfera pública'. Tem um significado maior do que somente 'espaço público'; inclui fachadas de prédios e tudo que pode ser visto ao nível dos olhos. Em razão disso, plinths são uma parte importante de prédios: o andar térreo, a cidade ao nível dos olhos. Um prédio pode ser feio, porém, com um plinth vibrante, a experiência pode ser positiva. 0 contrário também é possível: um prédio pode ser muito bonito, porém se o andar térreo é um muro cego, a experiência na rua pouco será positiva. (Karssenberg \& Hoff, 2015, p. 15)

Tentando entender a dinâmica da mobilidade dos modais não motorizados no bairro, foi produzido a partir de observação in loco o mapa dos usuários, pedestres e ciclistas (Figura 11). 0 mapa mostra uma presença considerável de pedestres e ciclistas no bairro. Os pedestres são vistos em maior número nas ruas principais do bairro e nas que ligam o interior do bairro às principais avenidas. Nota-se também que na proximidade do Timbó (principal comunidade da área), as ruas locais também abarcam maior movimentação de pedestres, além de ser destino de vários ciclistas. Os ciclistas usam, preferencialmente, as "Três Ruas", a Rua Rosa Lima dos Santos e Rua José Alexandre de Lira (perpendiculares à rua principal do bairro). A análise do mapa reforça a ideia de que os pedestres escolhem as ruas de maior movimentação, mais integradas, que possuem mais comércio e com locais âncoras (como escolas, postos de saúde e praças). Já os ciclistas escolhem locais com vias de boa infraestrutura, mas que as velocidades médias dos autos sejam menores, o que explica a falta de ciclistas na principal avenida do bairro, a Rua Empresário João Rodrigues Alves. 


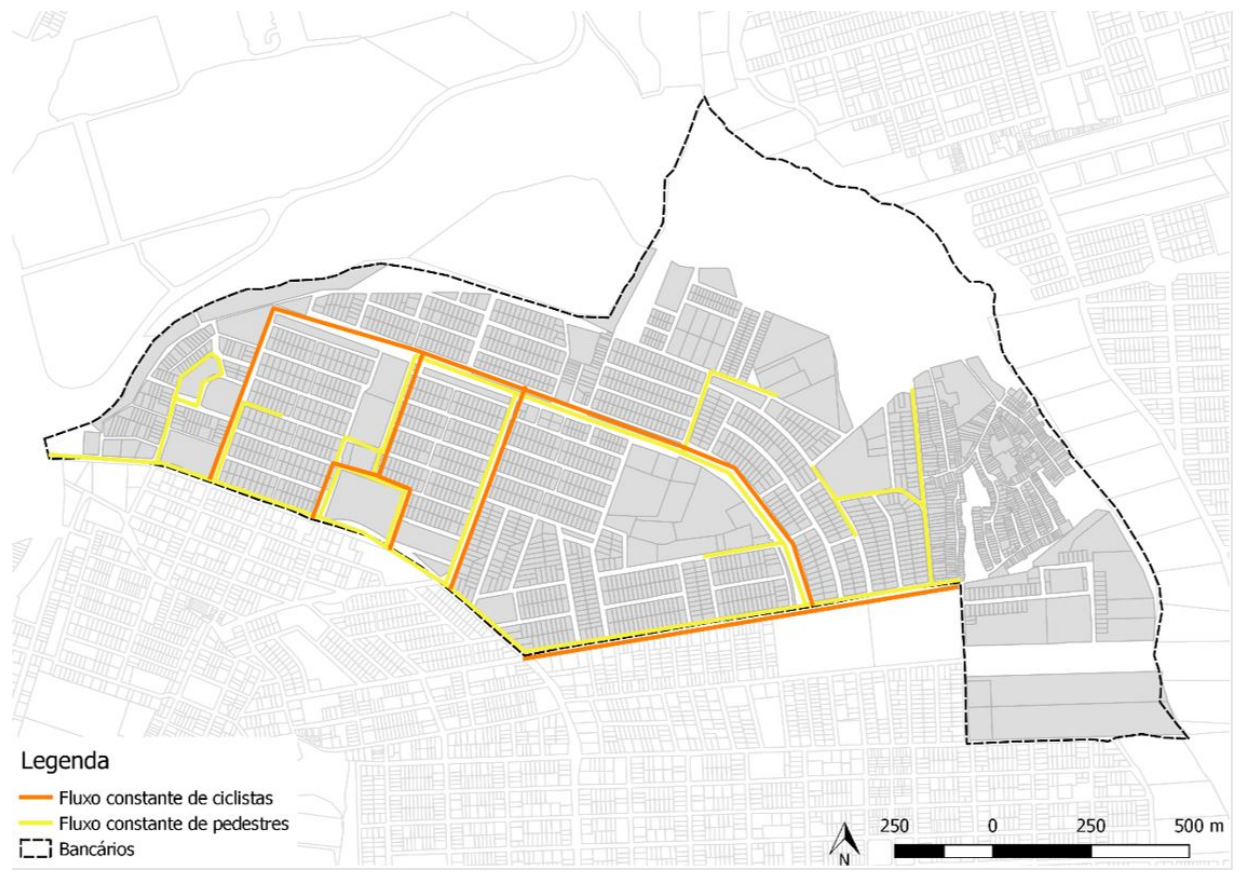

Figura 11 - Mapa de Usuários: fluxos de pedestres e ciclistas. Fonte: Autores, a partir da base de dados do LAURBE.

O Mapa-Síntese (Figura 12) nos mostra que a concentração de comércios no bairro está, principalmente, em três acessos: Rua Empresário João Rodrigues Alves, Rua Bancário Waldemar de Mesquita Accioly ("Três Ruas") e Rua Abelardo Pereira dos Santos. Nessas ruas também se encontram os principais polos atrativos do bairro, sendo a Praça da Paz na Rua Rodrigues Alves, comércios e centros religiosos nas "Três Ruas" e o comércio local na Rua Abelardo Santos. Na porção leste das "Três Ruas", há uma grande concentração de lotes institucionais, que margeiam um grande vazio urbano, que por sua localização com proximidade à comunidade do Timbó e frente à Rua Waldemar Accioly, mostra grande potencial para a intervenção que propõe a disciplina, estando próximo a uma certa infraestrutura do bairro entre Escola, USF e Posto de Polícia Militar.

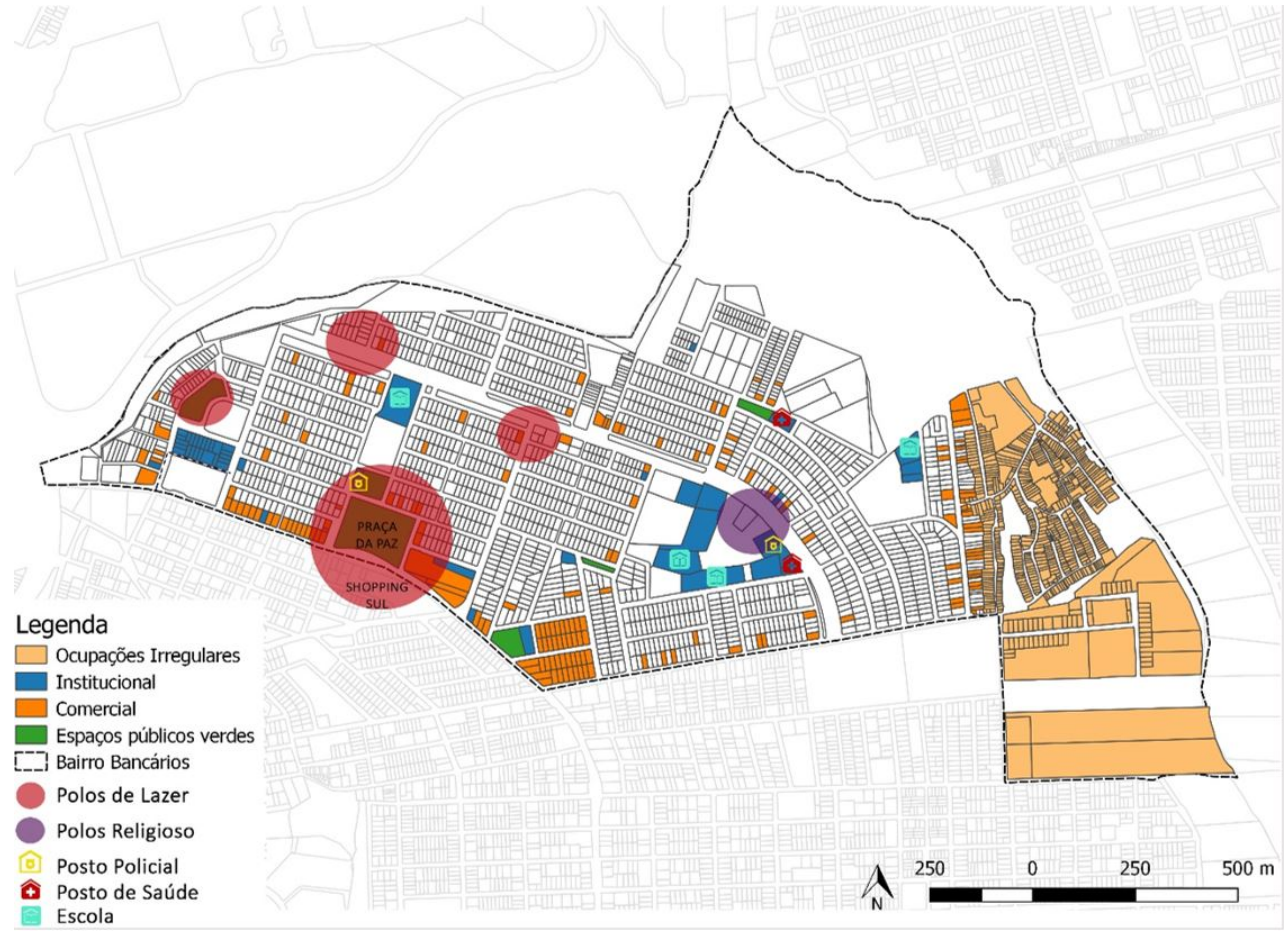

Figura 12 - Mapa-Síntese. Fonte: Autores, a partir da base de dados do LAURBE. 


\section{Criação de cenários}

Os bairros que seguem a lógica de ocupação e expansão como a do Bancários demandam um bom planejamento urbano para que situações extremas não cheguem a acontecer, e para isso é preciso estar atento às formas de ocupação que um espaço já consolidado pode oferecer. Mudar a dinâmica do favorecimento dos modais motorizados, oferecendo um maior leque de possibilidades aos pedestres e ciclistas para vivenciarem a cidade, constituem grandes impulsionadores da economia e vivacidade de bairros em constante crescimento.

As cidades precisam de planejadores urbanos e arquitetos que reforcem o pedestrianismo como uma política integrada da cidade para assim, desenvolver cidades vivas, seguras, sustentáveis e saudáveis. É igualmente urgente fortalecer a função social do espaço urbano como local de encontro, contribuindo para os objetivos da sustentabilidade social e de uma sociedade aberta e democrática. (Gehl, 2013, p. 6)

Pensando em formas de humanizar o bairro e torná-lo mais convidativo às pessoas e ciclistas, proporcionando espaços para que todos os tipos de modais possam desfrutar livremente do bairro, propõe-se neste trabalho a construção de três cenários possíveis de intervenções no Bairro Bancários.

A metodologia utilizada para construir as diretrizes projetuais no estudo foi baseada na Teoria dos Cenários desenvolvida por Rodrigues \& Santos (1995). Segundo os autores,

um cenário pode ser entendido como um estado de um sistema que se deseja conhecer, em um dado instante de tempo e devem ser entendidos como uma estimativa do que pode vir a acontecer em função das influências das variáveis Rodrigues \& Santos (1995, p. 443).

Portanto, "o objetivo dos cenários é identificar, de forma clara, um conjunto de possibilidades para o futuro" Rodrigues \& Santos (1995, p. 443). Seguindo ainda a análise de Rodrigues \& Santos, optou-se trabalhar com a classificação dos cenários Tendenciais-Alternativos, que são aqueles em que as políticas e situações não diferem radicalmente das tradicionais, procurando investigar as possibilidades estruturalmente distintas das tradicionais. Dessa forma, foram propostos três cenários alternativos para serem implantados no Bairro Bancários.

Os cenários surgem com as três principais emergências notadas no diagnóstico do local: o primeiro visa à Mobilidade Urbana, o segundo à Sustentabilidade e um terceiro visando ao Uso, Ocupação e Densidade Urbana.

\section{Cenário 1 - mobilidade urbana}

No primeiro cenário (Figura 13), enfatizou-se o potencial subutilizado das "Três Ruas" como uma importante via de conexão. Para isso, foi proposto na faixa central da rua um BRT (Bus Rapid Transit) que faria a conexão entre os Bairros de Mangabeira, Cidade Jardim Universitária, Anatólia, Bancários e Castelo Branco com o centro da cidade. Também é adicionada uma ciclovia que entremeia as árvores existentes nesta via, possibilitando aos ciclistas mais conforto e segurança, interligada a uma rota ciclável que interliga maior parte do bairro, tendo como eixo as "Três Ruas". Visando ampliar a conectividade entre os modais propostos e os bairros vizinhos (Jardim São Paulo e Anatólia), uma linha especial de microônibus já existente tem sua rota alterada para levar a demanda de passageiros desses outros bairros a essa nova via. Nas outras ruas do bairro, busca-se uma mudança em seus perfis, para que sejam implementadas calçadas mais largas e uma faixa bem definida de serviços e vegetação. 


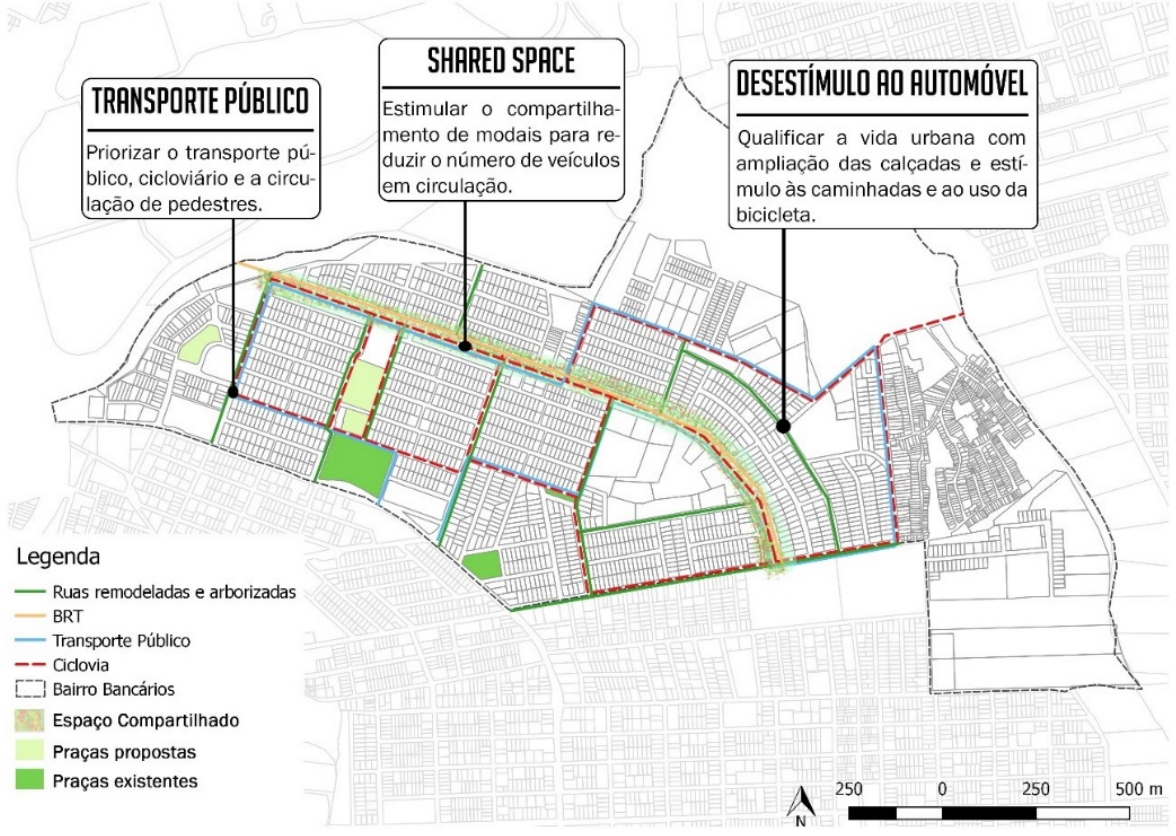

Figura 13 - Proposta do Cenário 1: Mobilidade Urbana. Fonte: Autores, baseado no Plano Diretor Estratégico de São Paulo.

\section{Cenário 2 - corredor verde}

No segundo cenário (Figura 14), o caráter verde do Bairro é potencializado, elevando as "Três Ruas" à posição de corredor verde. Através do fechamento da faixa central, as "Três Ruas" passam a ser um grande parque linear. Nesse cenário, o ponto direcional da proposta é o de Conectar Praças: espaços que hoje funcionam como praças subutilizadas ou informais passam a integrar um circuito de praças formais, interligados por uma infraestrutura de calçadas largas e arborizadas e ciclorrotas que permitem a conectividade dos pedestres e ciclistas ao longo do bairro, facilitando as condições de acessibilidade à Universidade Federal da Paraíba (UFPB). Com a possibilidade de ampliar a área verde e a indução do uso da bicicleta, essa proposta busca maior sustentabilidade do Bairro Bancários, contando ainda com hortas urbanas e pocket parks propostos ao longo de vários becos subutilizados do bairro, possibilitando a caminhada mais agradável e segura aos pedestres.

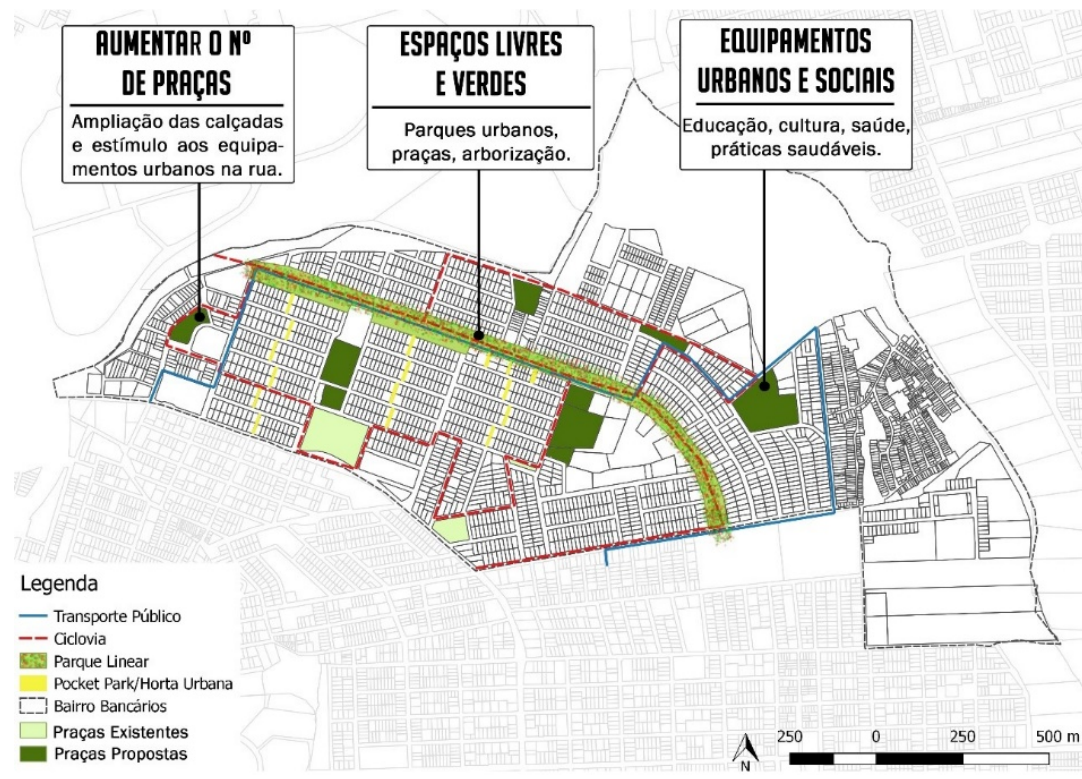

Figura 14 - Proposta do Cenário 2: Sustentabilidade. Fonte: Autores, baseado no Plano Diretor Estratégico de São Paulo. 


\section{Cenário 3 - uso, ocupação e densidade urbana}

As propostas desse cenário (Figura 15) buscaram minimizar a sensação de insegurança que hoje é vivida no bairro. As ações tomadas para alcançar esse objetivo afastaram-se de práticas hostis e visam levar mais pessoas às ruas e torná-las mais seguras a partir dos olhos das ruas, conceito lançado por Jane Jacobs (2011) em seu livro "Morte e Vida de Grandes Cidades". A principal mudança ocorre com o incentivo às edificações mistas, fachadas ativas e permeáveis, bem como a mudança no plano diretor sobre o adensamento da área, ampliando a situação para edificações de até oito pavimentos, contanto que misturem comércios e serviços no térreo e moradia nos pavimentos superiores, medida tal aplicada ao entorno imediato das "Três Ruas". Algumas quadras foram redesenhadas para que garantissem maior conectividade com o interior do bairro, tornando-o mais fluido e acessível aos pedestres. Os espaços livres públicos são incorporados pelo bairro, propondo-se uma grande área para um equipamento público que fomente a convivência, cultura e esportes na comunidade. Uma ciclorrota interliga os locais de maior interesse público do bairro. Para que as "Três Ruas" afastem-se do efeito barreira e de seu caráter de divisor do bairro, implantar-se-á um sistema de shared space (espaço compartilhado), minimizando a velocidade dos autos, tornando o espaço mais humano e seguro.

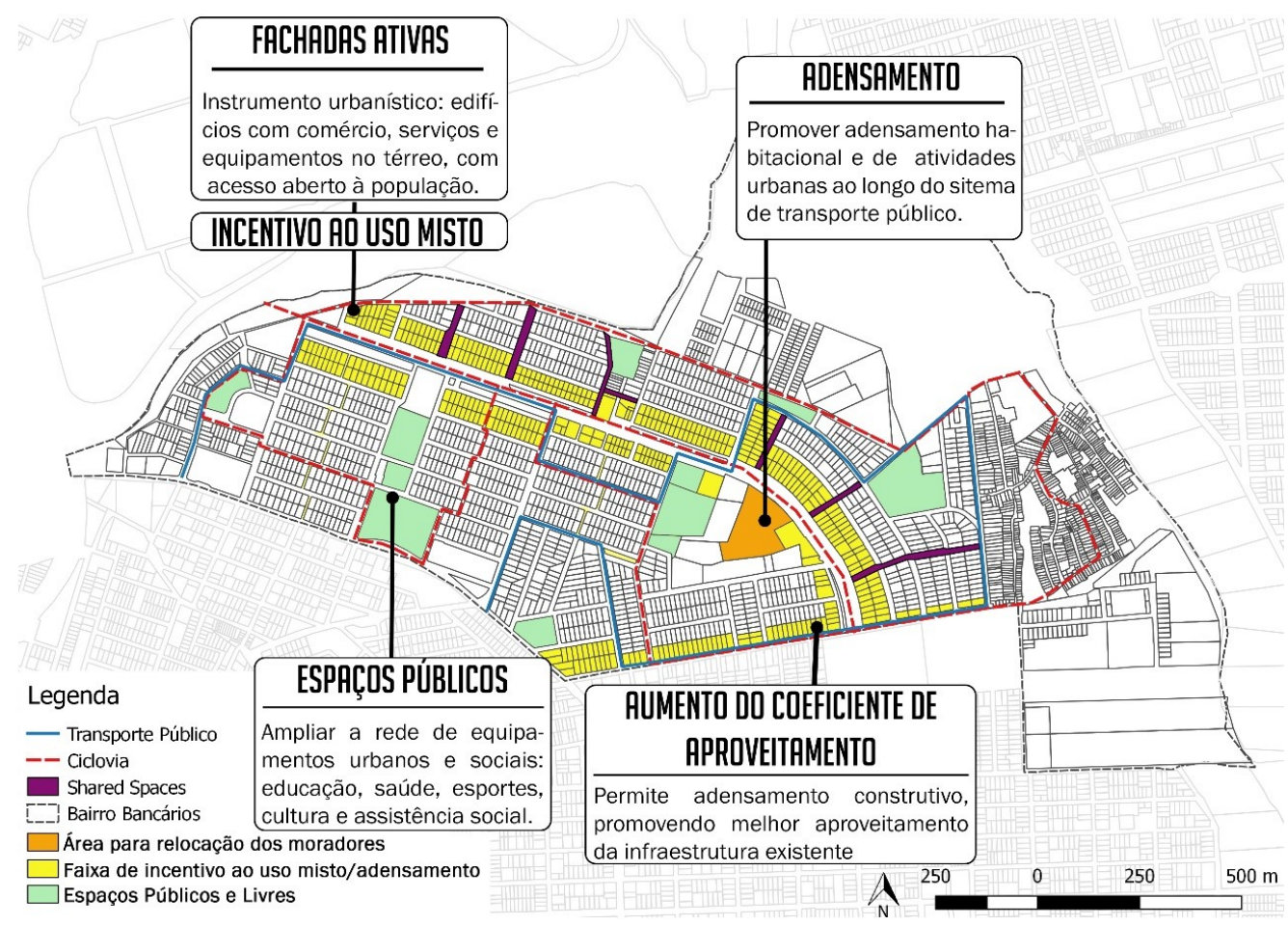

Figura 15 - Proposta do Cenário 3: Uso e Ocupação do Solo. Fonte: Autores, baseado no Plano Diretor Estratégico de São Paulo.

\section{Escolha dos cenários}

Através da tabela (Tabela 1) com dezesseis diretrizes-guia foi possível quantificar e analisar a relevância e qualidade das propostas para o bairro, com a seleção das principais características que os bons espaços públicos resguardam, segundo as diretrizes defendidas por Jacobs (2011), Gehl (2013) e Karssenberg \& Hoff (2015), entre outros. 
Tabela 1 - Critério de seleção dos Cenários

\begin{tabular}{cccc}
\hline & CENÁRIO 1 & CENÁRIO 2 & CENÁRIO 3 \\
\hline Escala Humana & 2 & 3 & 5 \\
Espaços Públicos & 2 & 5 & 5 \\
Conforto Ambiental & 3 & 5 & 3 \\
Identidade & 2 & 5 & 4 \\
Legibilidade & 3 & 3 & 5 \\
Marcos & 3 & 4 & 3 \\
Paisagismo & 3 & 5 & 5 \\
Conectividade & 4 & 3 & 3 \\
Transporte Público & 5 & 2 & 4 \\
Transporte Ciclável & 5 & 5 & 5 \\
Caminhabilidade & 2 & 4 & 5 \\
Sociabilização & 2 & 4 & 4 \\
Sustentabilidade & 3 & 5 & 5 \\
Segurança & 1 & 2 & 4 \\
Permanência & 2 & 5 & 4 \\
Hábito Saudável & 2 & 5 & 69 \\
\hline
\end{tabular}

Fonte: Autores.

Nesse sentido, foram determinados valores de avaliação de acordo com a presença ou ausência das diretrizes-guia no cenário, sendo o número 1 (fraco) e 5 (muito presente). 0 resultado mostra uma equivalência entre o segundo e terceiro cenário, indicando a necessidade de optar-se pelo que tem, entre suas características, potencial maior em cada um dos cenários, criando assim, um quarto cenário que reúna mais características de um espaço público ideal.

\section{Cenário escolhido: infraestrutura verde e caminhabilidade}

O cenário escolhido (Figura 16) reúne em sua proposta os pontos mais fortes de cada um dos três cenários propostos, levando em conta, prioritariamente, formas de incentivar e fornecer estrutura adequada para a movimentação de pessoas e ciclistas nas ruas, de modo que os caminhos sejam mais confortáveis, convidativos e seguros, não ignorando a forte presença que os automóveis têm no bairro, organizando o espaço de forma democrática ao uso de qualquer modal. Por isso, o principal conceito que se propõe é o de criar espaços livres públicos verdes conectados entre si, definindo um sistema urbano. Essa conexão é feita por uma série de infraestruturas lançadas no bairro, como uma ciclorrota que conecta as praças, assim como as ruas que ligam a estas serão redesenhadas de forma a ampliar e arborizar os passeios; os 11 becos vazios presentes no bairro serão preenchidos com pocket parks ou hortas urbanas. Para melhoria da segurança do bairro, faz-se necessário implantar uma mudança no uso e ocupação do solo, com o incentivo ao uso misto nas edificações, com fachadas ativas que ajudem na vigilância do espaço público, além de incentivar a caminhada. No quesito de acessibilidade ao bairro, são propostas melhorias no transporte público, criando uma faixa exclusiva para um BRT que cortará o bairro, conectando o Bairro Bancários e seus bairros vizinhos ao centro da cidade, além de oferecer uma linha de micro-ônibus com a função de interligar o resto do bairro ao BRT, atendendo ao limite máximo de caminhada de $500 \mathrm{~m}$, encurtando caminhos e tornando a caminhada mais segura, sendo proposto o redesenho de algumas quadras no bairro, possibilitando a implantação de shared spaces nas novas ruas criadas, facilitando o acesso da comunidade do Timbó ao bairro, como também aos próprios moradores.

Para que as pessoas optem por caminhar, a caminhada deve ter um propósito. Em termos de planejamento, o propósito é atingindo pelo uso misto ou, mais exatamente, criando um adequado equilíbrio de atividades dentro de uma distância entre elas possível de ser completada a pé (Speck, 2017, p. 73). 


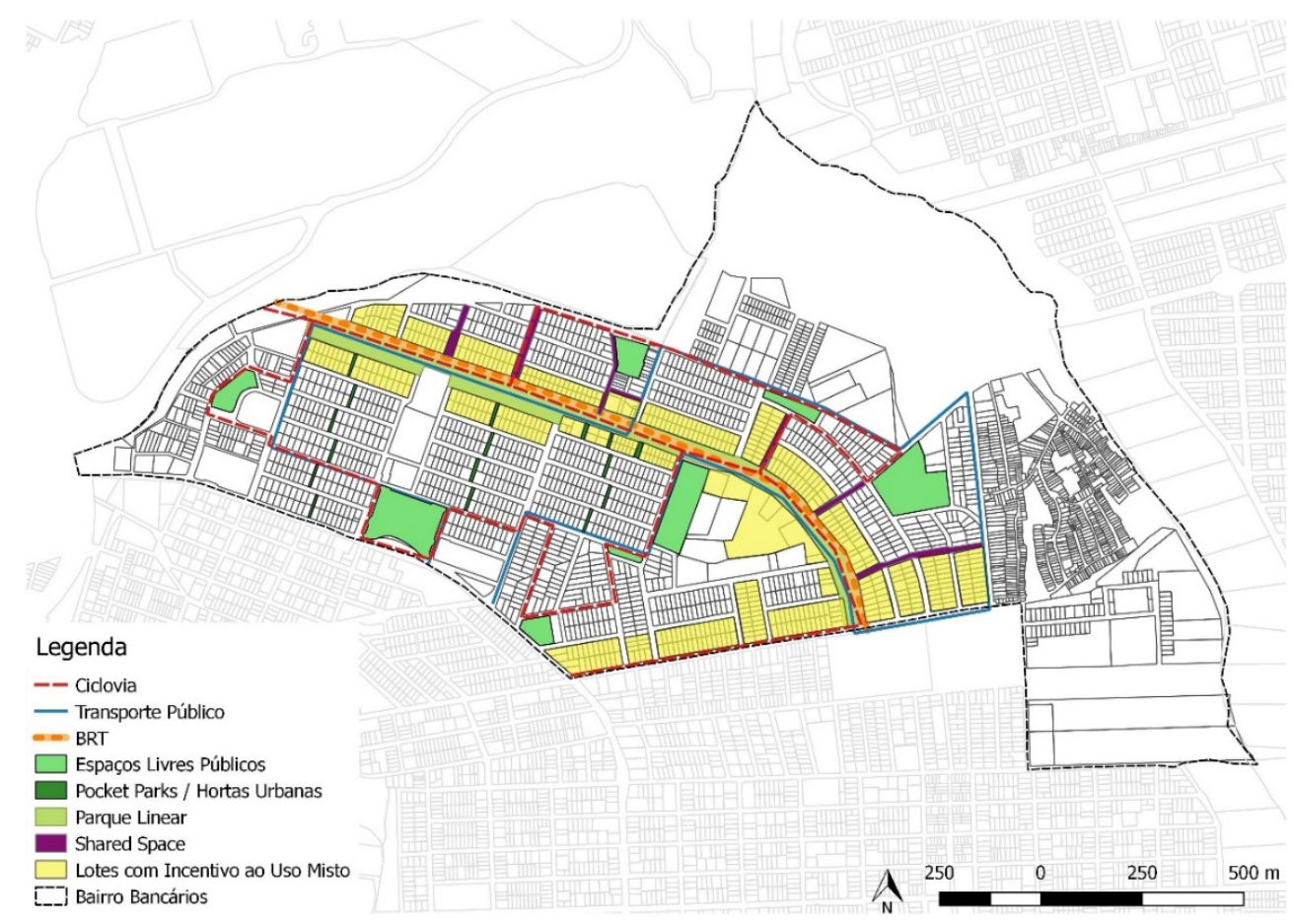

Figura 16 - Cenário Escolhido: Infraestrutura verde e Caminhabilidade. Fonte: Autores.

\section{Resultados}

O cenário escolhido apontou um entendimento e busca da infraestrutura verde, agrupando o que havia sido proposto nos cenários das etapas anteriores.

A infraestrutura verde se difere da percepção popular sobre a proteção e planejamento de áreas verdes. Para muitas pessoas, espaços abertos são apenas lugares que ainda não se desenvolveram e espaços verdes se referem a parques isolados, praças ou áreas naturais. [...] A infraestrutura verde enfatiza a importância de espaços verdes públicos como parte de um sistema interconectado que é protegido e gerenciado pelos benefícios ecológicos que eles fornecem. [...] a infraestrutura verde proporciona uma estrutura para conservação e desenvolvimento que assegura a necessidade de oferecer ambientes para as pessoas conviverem, trabalhar, fazer compras e aproveitar a natureza (Benedict \& McMahon, 2006, p. 1-2, tradução feita pelos autores).

Seguindo esses conceitos, juntamente, com as análises do diagnóstico, foi proposto um conjunto de projetos que visam à implementação da infraestrutura verde no bairro, construindo um sistema urbano. De forma a demonstrar e visualizar brevemente os projetos, foram selecionadas as principais intervenções que definirão a proposta para o bairro: o redesenho das ruas, a criação de espaços verdes públicos e a implantação do parque linear das "Três Ruas".

\section{O redesenho das ruas}

A escolha das ruas (Figura 17) ocorreu com base naquelas que tinham maior potencial de mudança, como as de grandes extensões, bem como as que hoje já apresentam características de uso misto, compondo os principais eixos de ligações para os espaços livres públicos propostos. A ideia central de redesenho das ruas se baseia na proposta de corredores e vias verdes que possibilitem percursos caminháveis mais agradáveis, aumentando a vegetação urbana pouco existente. A caminhabilidade incentivada na proposta é importante para uma melhor mobilidade e segurança urbana, sendo a qualidade das calçadas e a arborização, peças fundamentais para um maior conforto e segurança dos pedestres. 0 redesenho das ruas (Figuras 18, 19 e 20) 
implica aumento da largura das calçadas, de forma a conter uma acessibilidade eficiente aos usuários, implantando as quatro zonas necessárias: (1) Zona de Fachadas e Comercialização; (2) Zona Livre Pedonal; (3) Zona de Mobiliário e Vegetação; e (4) Zona de Borda/Serviço. Como também a implantação de ciclovias e faixas exclusivas para transportes público coletivo.

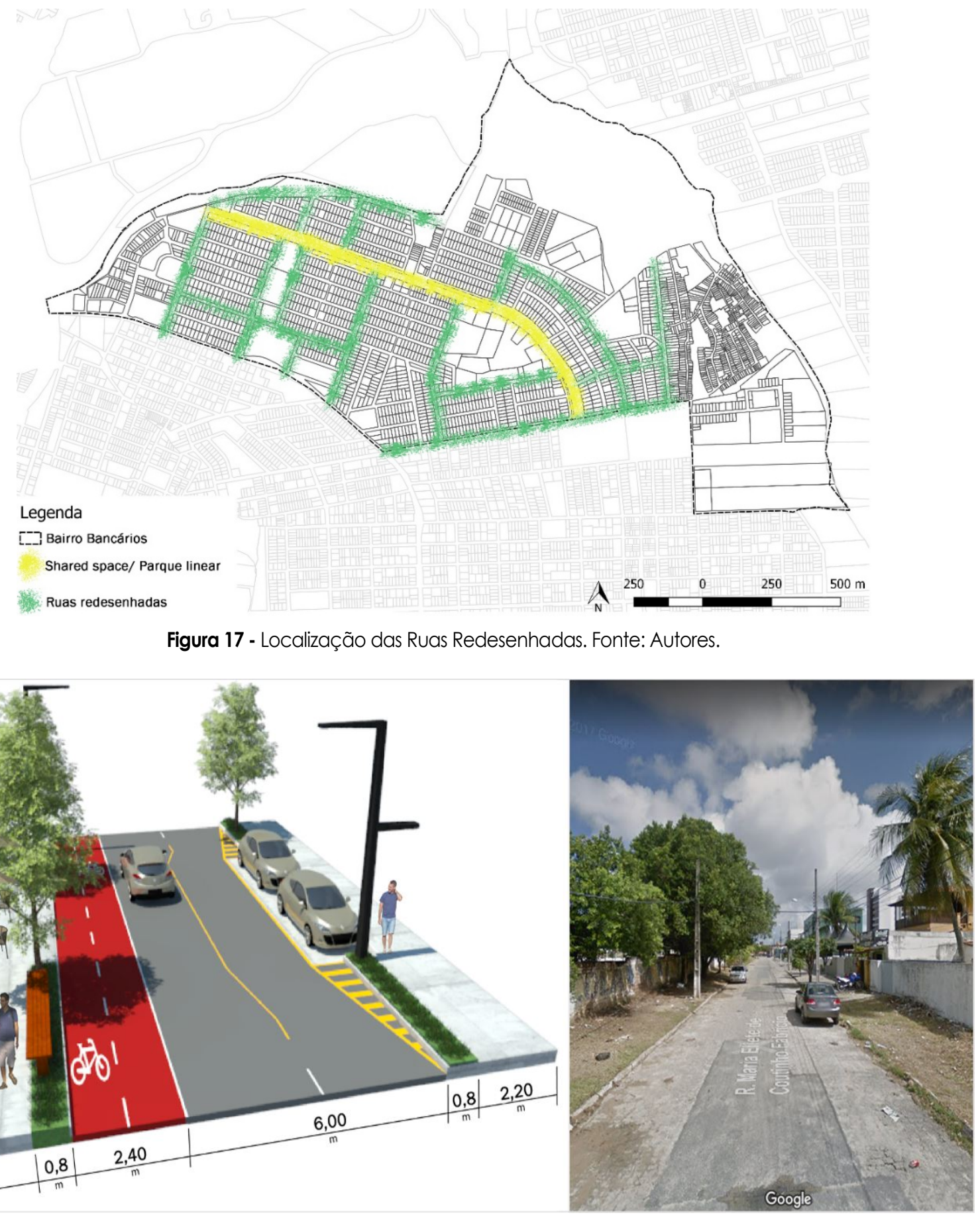

Figura 18 - Redesenho da R. Maria Eliete de Coutinho Fabrício. Fonte: Autores. 


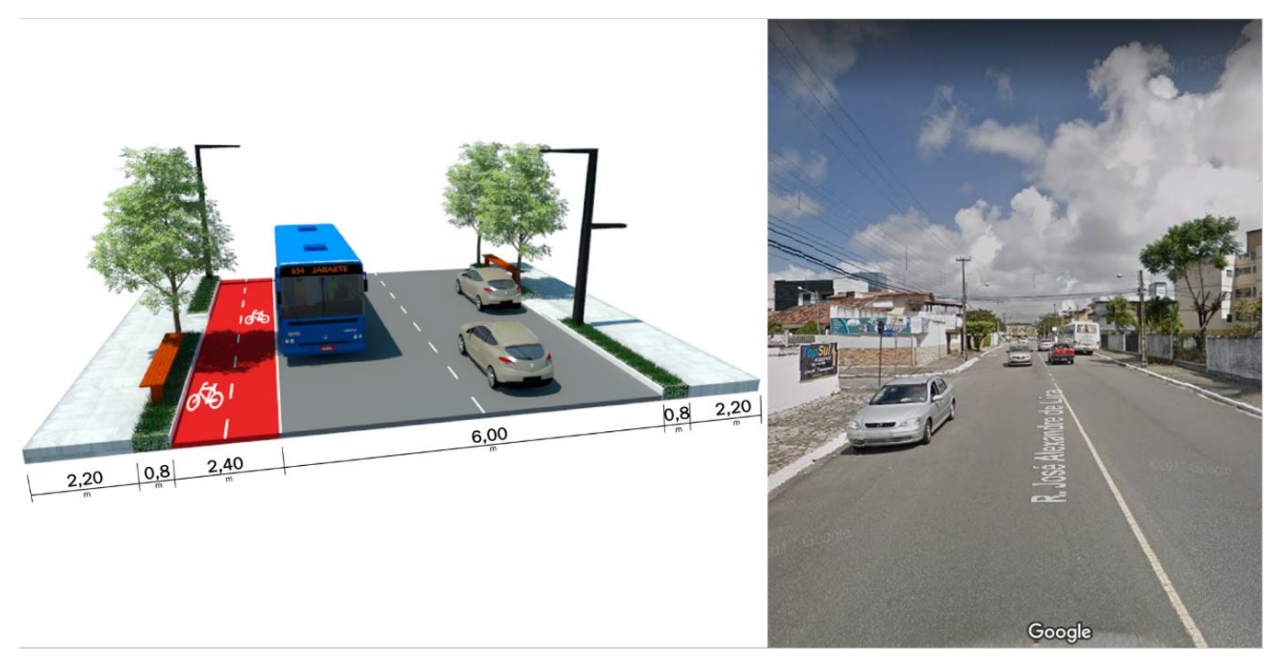

Figura 19 - Redesenho da R. José Alexandre de Lira. Fonte: Autores.

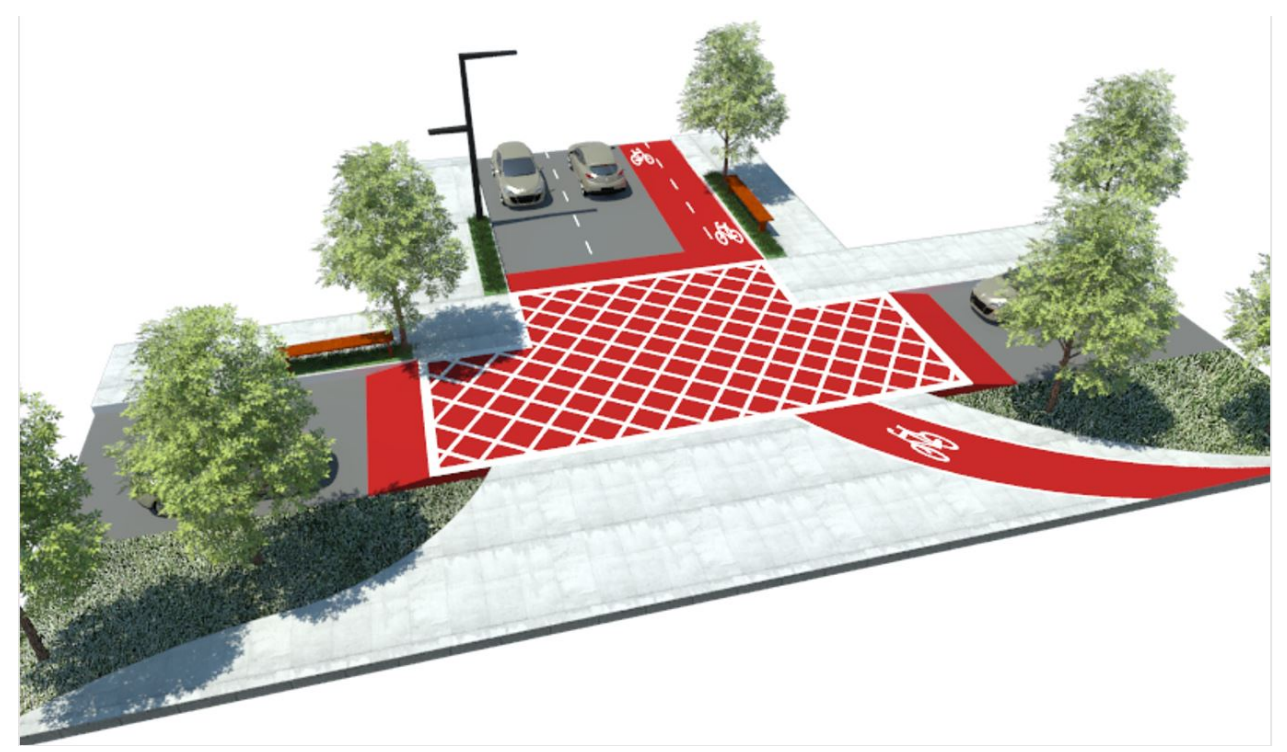

Figura 20 - Esquema de Cruzamentos com o Parque das "Três Ruas". Fonte: Autores.

\section{Espaços livres públicos}

Propor novos espaços livres públicos verdes e de permanência, tão pouco presentes no bairro, foi a maior preocupação do trabalho, uma vez que moram muitos estudantes, as atividades que acontecem são proporcionais a essa população, apresentando um caráter bastante esportivo e recreativo, portanto, é emergente a necessidade de bons espaços públicos que ofereçam essas atividades. A proposta visa selecionar os lotes que já apresentam funções semelhantes, mas não eram consolidadas, como a Praça Canafístula (Figura 21), que não obtinha nenhuma infraestrutura, antes era utilizada como campo de futebol pelos moradores. Outra característica bastante evidente na área é a presença de pequenos becos, que totalizam onze unidades, funcionando como um atalho para pedestres e veículos, porém apresentam um elevado grau de insegurança por serem rodeados por fachadas cegas. Dessa forma, esses espaços são aproveitados com uma série de pocket parks (Figura 22) que atuam como pequenos respiros urbanos, contendo quiosques e hortas urbanas, além de possuir uma área verde extensa pensada para atrair os olhos dos pedestres. 

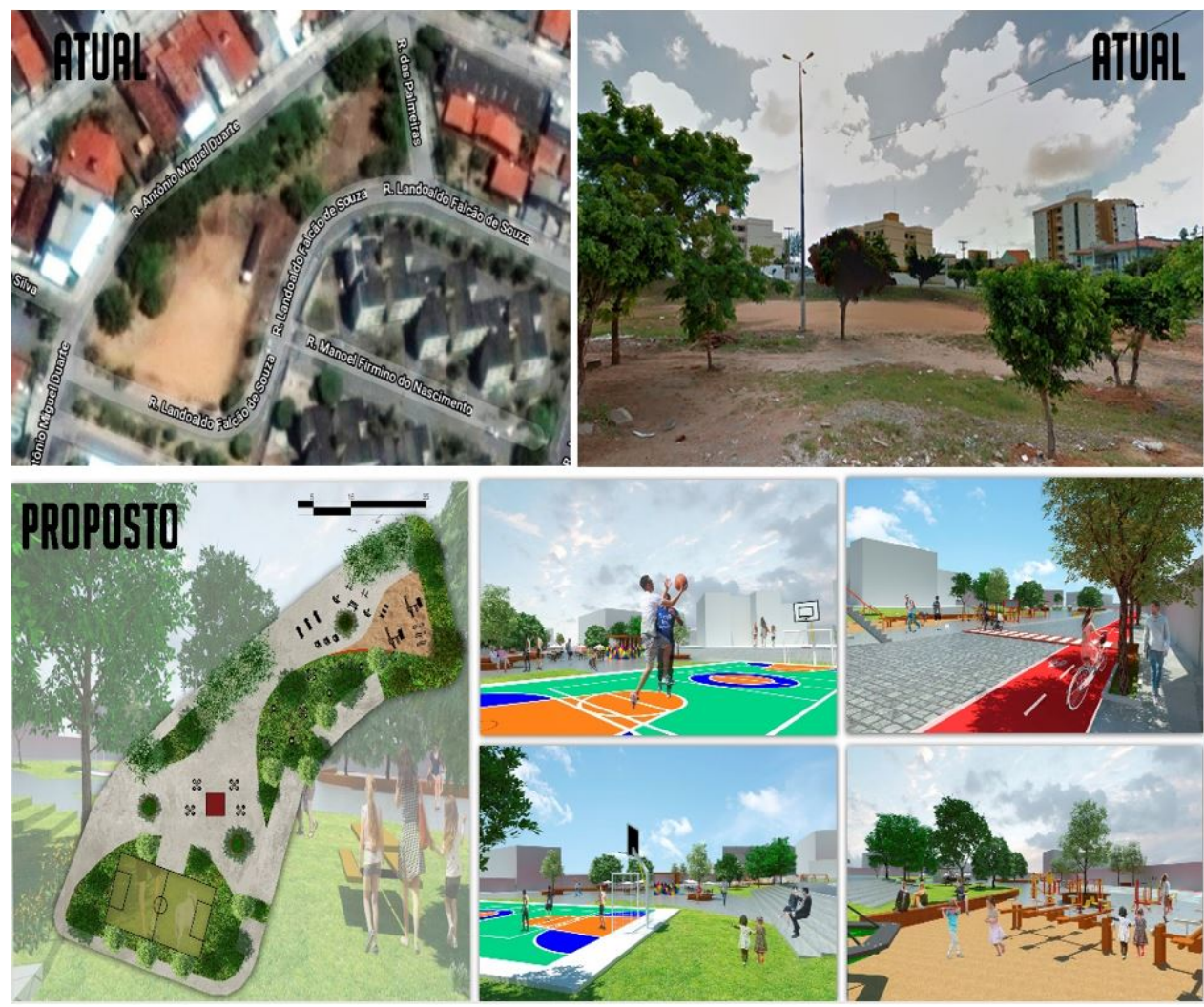

Figura 21 - Proposta da Praça Canafístula. Fonte: Autores.

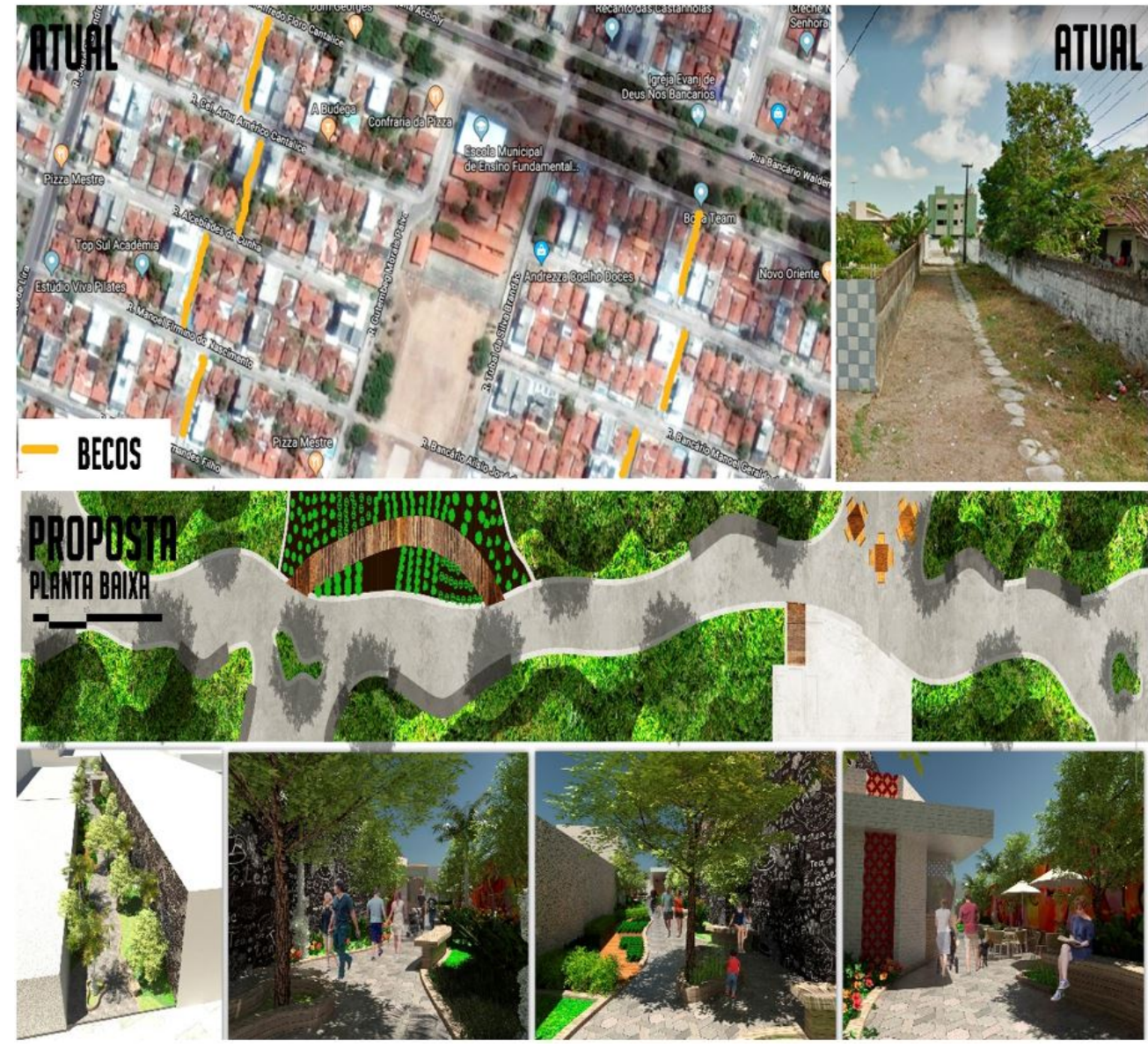

Figura 22 - Proposta para os becos: Pocket Parks. Fonte: Autores. 


\section{Parque linear das "Três Ruas"}

Maior equipamento proposto, o Parque das "Três Ruas" (Figuras 23 e 24) segue toda a extensão da avenida. As "Três Ruas" é composta por quatro ruas, sendo uma de mão dupla asfaltada e outras duas que recebem o trânsito local, com dois largos canteiros arborizados. Hoje, as faixas centrais são abertas exclusivamente aos pedestres durante o período entre $5 \mathrm{~h} 00$ e $7 \mathrm{~h} 00$ para caminhadas. Absorvendo esse conceito e pensando em diminuir a velocidade dos carros, dando prioridade aos pedestres e ciclistas, une-se a faixa central asfaltada com os canteiros arborizados para transformar o espaço em um extenso parque linear, concentrando diversos equipamentos para uso de lazer dos usuários.
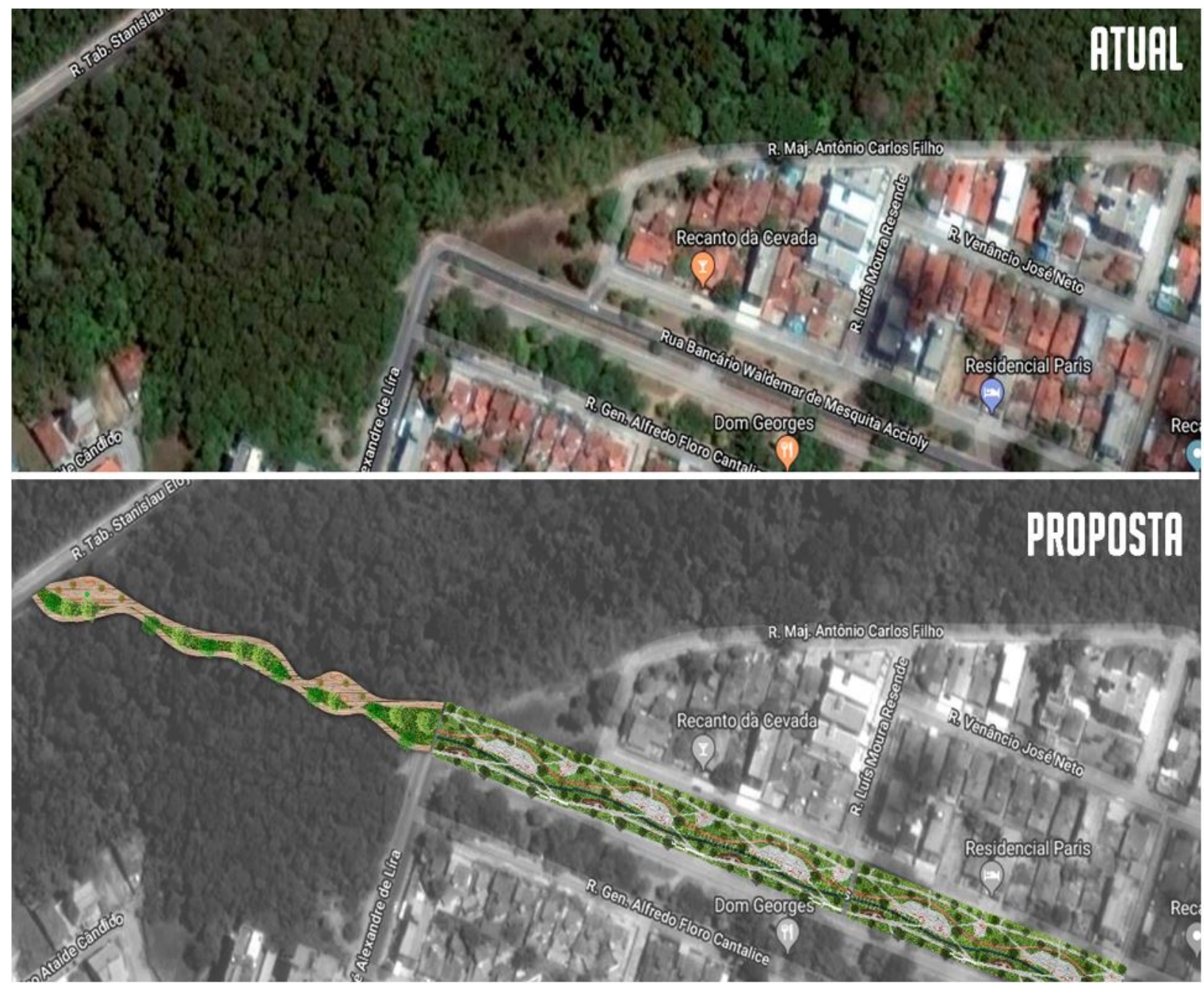

Figura 23 - Proposta para as "Três Ruas": Parque Linear e Ponte. Fonte: Autores. 

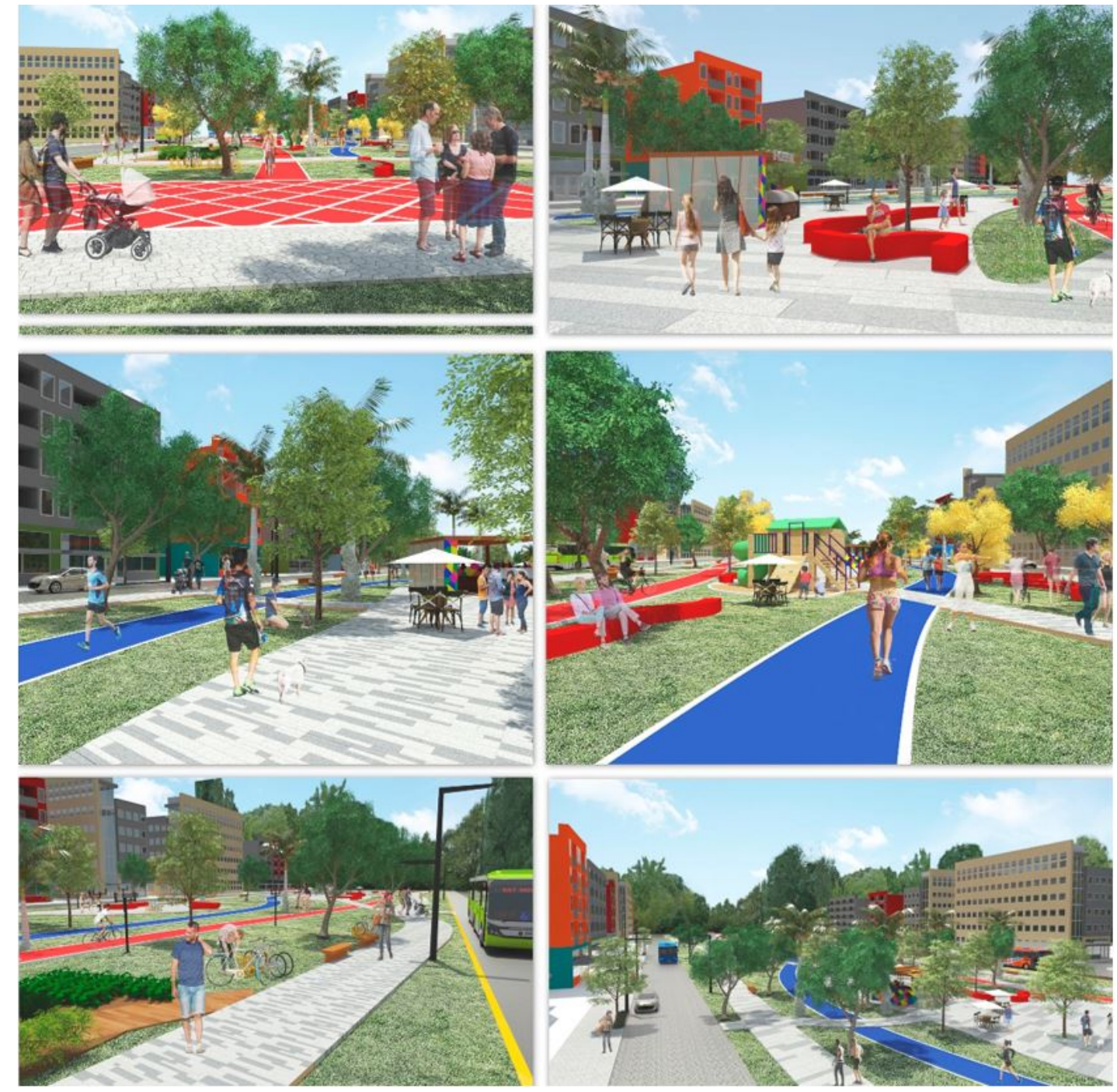

Figura 24 - Proposta para o Parque Linear das "Três Ruas". Fonte: Autores.

Para melhor racionalização do projeto, visando à execução e absorvendo o conceito da infraestrutura verde, partiu-se de um sistema modular que concentra os diversos usos propostos e os distribui por toda extensão do parque. Propõe-se uma ciclofaixa que transcorre todo o parque, sendo parte da ciclorrota proposta para o bairro. Sugere-se ainda uma pista de cooper, oferecendo infraestrutura adequada à atividade já praticada na rua, incentivando os hábitos saudáveis dos moradores e integrando mais um importante instrumento de infraestrutura verde para o bairro. No centro do parque há empraçamentos que contam com quiosques e área de lazer para crianças, além disso, há espaços suficientes a serem apropriados pela comunidade de acordo com a demanda e necessidade desses usuários. Existem ainda hortas urbanas e paraciclos, além de equipamentos de infraestrutura que melhoram a relação do usuário com o parque.

Juntamente com o Parque Linear das "Três Ruas", sugere-se a construção de uma ponte (Figura 25) que conecta toda a infraestrutura criada para os modais não motorizados com a via perimetral à UFPB. Ela visa dar continuidade para pedestres e ciclistas, sendo um ponto mais fácil de acesso do interior do Bairro Bancários até a UFPB, incentivando e facilitando a caminhada dos estudantes até a Universidade.

Trazendo os conceitos da sustentabilidade e da infraestrutura e engenharia verde, a ponte é idealizada em estrutura de madeira, elevando-se do solo em sua maior extensão, curvando-se entre as árvores para que não afete nenhuma delas para a instalação desse equipamento. Possui um caminho para pedestres e outro para ciclistas, onde esses encontram-se em pontos de contemplação, ofertando mais um local de lazer para o bairro. 


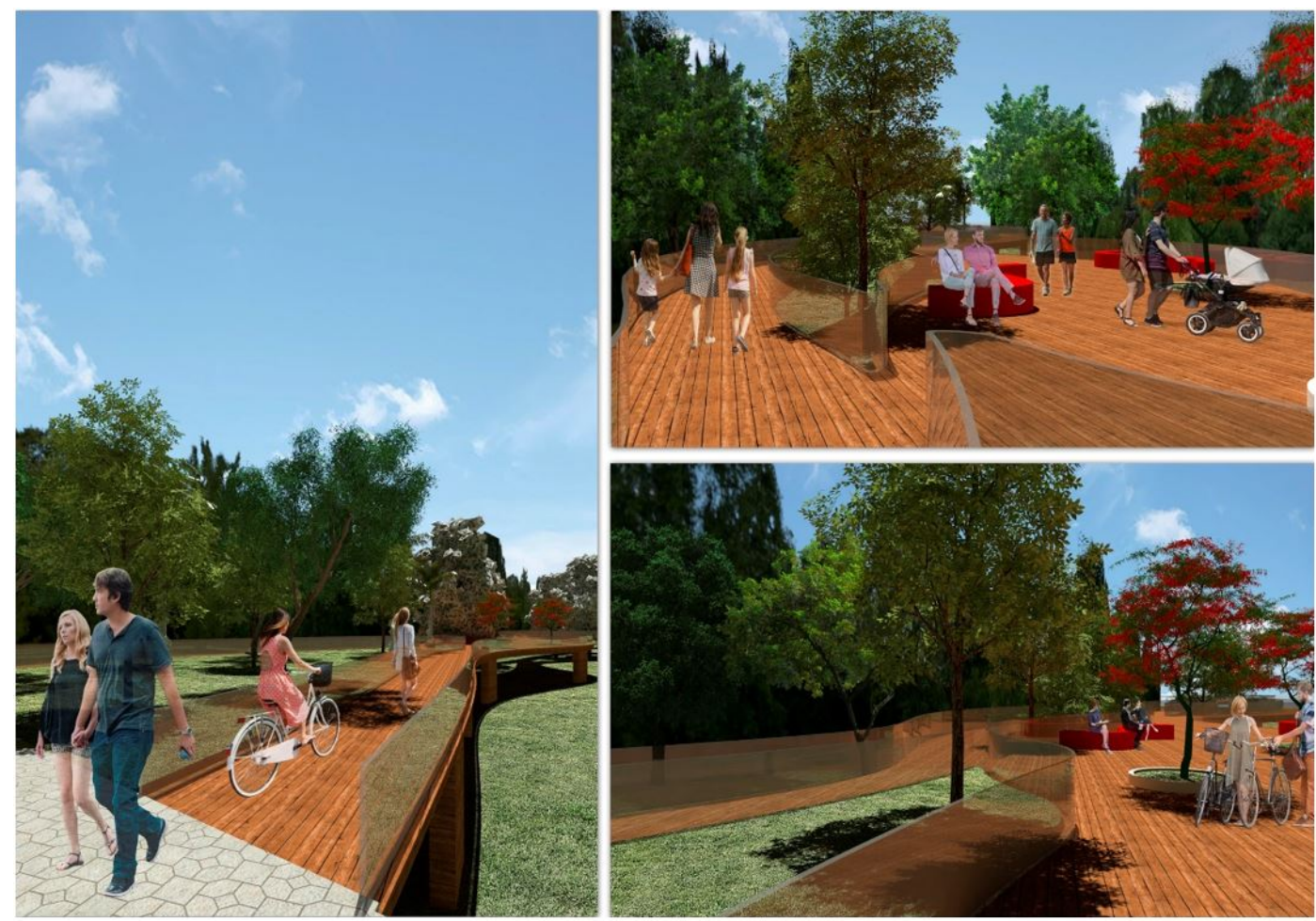

Figura 25 - Proposta para a Ponte. Fonte: Autores.

\section{Considerações finais}

Por meio do estudo e diagnóstico do Bairro Bancários, foi possível perceber a lógica de ocupação e distribuição do espaço público que vem atuando desde o seu surgimento até os dias atuais. Por se tratar, inicialmente, de uma área periférica, o bairro não recebeu a atenção necessária quanto ao seu crescimento, não atentando principalmente à infraestrutura ofertada, que cresceu desenfreadamente, preocupando-se, ao que parece, em abraçar da maneira mais confortável os veículos motorizados, esquecendo-se de que o bairro tem uma vocação enorme para a atuação de uma população jovem e saudável.

O desenvolvimento deste trabalho propõe soluções urbanísticas alinhadas ao conceito da infraestrutura verde, buscando a criação de melhores espaços públicos. Bairros que já se encontram consolidados tanto a ocupação quanto a infraestrutura implantada são passiveis, sim, de mudanças. A infraestrutura verde pode nascer juntamente com uma ocupação, mas também pode ser adaptada facilmente no meio urbano. Pequenas soluções implantadas nesse trabalho, como canteiros arborizados e drenantes, maior interação dos cidadãos com a natureza, tanto através de parques urbanos como de hortas comunitárias, a proposição de ambientes confortáveis e convidativos à caminhada, a prática de ciclismo e o desencorajamento do uso de modais poluentes, contribuem para um maior nível de sustentabilidade no planejamento urbano, além de trazer melhorias consideráveis à saúde da população.

Requerendo investimentos estruturantes consideráveis, ao lado de intervenções pontuais sistemáticas não menos importantes, ressaltando ainda os aspectos ligados às possibilidades reais de que as operações urbanas sugeridas aqui venham a ser implementadas. Os diversos fatos aqui posicionados são também resultantes da interação de ações e projetos e do jogo de interesses dos atores que interagem no espaço urbano. Frente às conhecidas dificuldades de se fazer tais transformações, num ambiente construído complexo, podem envolver na sua promoção diversos atores urbanos (em combinação conflito), de forma gradual, considerando etapas de construção no espaço e no tempo, ou não.

Pode-se dizer que, dadas a localização espacial e a lógica da dinâmica intraurbana de João Pessoa, o ambiente construído objeto dos estudos, englobando o Bairro dos Bancários como território referencial, 
representou espaço de transição entre os lugares consolidados mais antigos do tecido urbano e o "novo", este como uma excrescência desenhada ao longo do vetor de crescimento sudeste da cidade.

Atualmente, a estrutura físico-territorial, objeto das pesquisas desenvolvidas, situa-se em lugar estratégico da cidade, englobando elementos que sugerem o desenvolvimento de uma nova centralidade urbana, dadas a localização, atração de viagens, densidade de infraestrutura e equipamentos e população, bem como a consolidação de corredor de comércio e serviços ao longo da via principal do Bairro dos Bancários (Rua Empresário Rodrigues Alves) (ver Figura 8). Não obstante a Rua Waldemar de Mesquita Accioly ("Três Ruas") se apresentar como certa "estrutura adormecida", com "barreiras" naturais e construídas nas suas extremidades que limitam as suas potencialidades de estruturação urbana, por outro lado, é justamente a sua localização que pode representar fator-chave abrindo "portas" para a realização das ideias aqui apresentadas.

De alguma forma, as "Três Ruas" se prestam, hoje, como rota alternativa de ligação a grandes equipamentos instalados em sua área de influência, a exemplo do Shopping Mangabeira, a sudeste da cidade, e da Universidade Federal da Paraíba. A requalificação daquela estrutura pode inseri-la, inclusive, como nova porta de entrada amigável e verde àqueles equipamentos, valorizando e podendo trazer novos significados urbanos. Daí o reconhecimento social desses papéis nos leva a considerar, dentre outros, especialmente o instrumento das operações urbanas consorciadas (Estatuto da Cidade, Dispositivos Constitucionais da Lei n. 10.257, de 10 de julho de 2001), onde se visualizam as intervenções possíveis na área de estudo coordenadas pelo poder público municipal, com a participação de outras instituições, de proprietários, moradores, usuários permanentes e investidores privados, com o objetivo de alcançar as transformações urbanísticas estruturais desejadas, com a melhoria e a valorização do meio ambiente natural e construído. Nesse quadro, recomendam-se intervenções por etapas, a partir da estrutura das "Três Ruas", visando ao envolvimento e à desejada "adoção social" da(s) etapa(s) implantada(s), para que se tenha a almejada e verdadeira legitimidade das ações, que podem ter intervenções singelas participantes das etapas ao longo da estrutura principal.

A requalificação de áreas como essa necessita da ação tanto de governos como da iniciativa privada e da própria população. Clamar por mudanças na forma de planejar o meio urbano, ajuda a encorajar a atuação de medidas alternativas e sustentáveis na cidade. A infraestrutura verde é uma forma amigável e interessante de trazer soluções sustentáveis e de mudar a forma como vivenciamos a cidade, incentivando a população a ter práticas mais saudáveis e a respeitar e usufruir da vegetação existente de forma inteligente.

\section{Referências}

Associação Brasileira de Cimento Portland - ABCP. (2017). Programa soluções para cidades - controle de inundações - programa ruas verdes de Portland, Oregon/EUA. São Paulo: ABCP. Recuperado em 21 de dezembro de 2017, de http://www.solucoesparacidades.com.br

Benedict, M. A., \& McMahon, E. T. (2006). Green infrastructure: linking landscapes and communities (2. ed., Vol. 1). Washington: Island Press.

Bentes, J. C. G. (2014). Dispersão urbana no médio paraíba fluminense (Tese de doutorado). Universidade de São Paulo, São Paulo.

Cormier, N. S., \& Pellegrino, P. R. M. (2008). Infraestrutura verde: uma estratégia paisagística para a água urbana. Paisagem Ambiente, (25), 125-142.

Gehl, J. (2013). Cidades para pessoas (2. ed., Vol. 1). São Paulo: Perspectiva.

Hannes, E. (2015). Infraestrutura verde como instrumento de legislação urbana: uma análise do plano diretor estratégico de São Paulo. Cidades Verdes, 3(6), 55-61. 
Herzog, C. P., \& Rosa, L. Z. (2010). Infraestrutura Verde: sustentabilidade e resiliência para a paisagem urbana. Revista Labverde, (1), 92-115. http://dx.doi.org/10.11606/issn.2179-2275.v0i1p92-115.

Jacobs, J. (2011). Morte e vida de grandes cidades (3. ed., Vol. 1). São Paulo: WMF Martins Fontes.

Karssenberg, H., \& Hoff, M. V. T. (2015). A cidade ao nível dos olhos: lições para os plinths. Porto Alegre: EdiPUCRS.

Negrão, A. G., Lira, A. H., Castor, D. C., \& Silveira, J. A. R. (2016). A produção da cidade: combinações e conflitos no setor sudeste de João Pessoa/PB. In Pluris: 7o Congresso Luso Brasileiro para o Planejamento Urbano, Regional, Integrado e Sustentável - Contrastes, Contradições e Complexidades (pp. 07). Maceió: FUNDEPES.

Negrão, A. G.; Silveira, J. A. R. (2016). Conjuntos habitacionais populares e periferização: a produção e a apropriação do setor sudeste de João Pessoa/ PB. In A. G. Negrão \& J. A. R. Silveira (Eds.), Lugares e suas Interfaces Intraurbanas: transformações urbanas e periferização (pp. 322-328). João Pessoa: Editora da UFPB.

Rodrigues, F. A. H., \& Santos, M. P. S. (1995). A criação de cenários através da análise de impactos cruzados: Uma revisão bibliográfica aplicada à avaliação de alternativas de transporte. In Anais do IX ANPET - Congresso de Pesquisa e Ensino em Transportes (pp. 442-453). São Carlos: ANPET.

Rogers, R. (2001). Cidades para um pequeno planeta (2. ed., Vol. 1). Lisboa: GG.

Scocuglia, J. B. C. (1999). A política habitacional do BNH no Brasil pós-64 e seus reflexos na expansão urbana de João Pessoa. João Pessoa: Editora da UFPB.

Speck, J. (2017). Cidade caminhável (Tradução Anita Dimarco, Anita Natividade, I reimpr. da I ed.). São Paulo: Perspectiva.

Editor: Harry Bollmann

Recebido: Jan. 06, 2018

Aprovado: Ago. 28, 2018 